Neoplasia: The process of abnormal and uncontrolled growth of cells. The product of neoplasia is a neoplasm (a tumor).

\title{
Mortality by neoplasia and cellular telephone base stations in the Belo Horizonte municipality, Minas Gerais state, Brazil ${ }^{2}$
}

\author{
Adilza C. Dode a,b,e,*, Mônica M.D. Leão ${ }^{c}$, Francisco de A.F. Tejo ${ }^{\mathrm{d}}$, Antônio C.R. Gomes ${ }^{\mathrm{e}}$, Daiana C. Dode ${ }^{\mathrm{e}, \mathrm{f}}$,

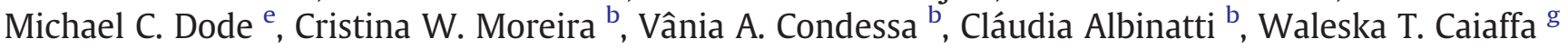 \\ a Minas Methodist University Center Izabela Hendrix, Belo Horizonte City, Minas Gerais State, Brazil \\ b Municipal Government of Belo Horizonte, Municipal Health Department, Belo Horizonte City, Minas Gerais State, Brazil \\ c UFMG-Universidade Federal de Minas Gerais-Belo Horizonte, Environmental and Sanitary Engineering Department, Belo Horizonte City, Minas Gerais State, Brazil \\ d UFCG-Universidade Federal de Campina Grande, Center of Electrical Engineering and Informatics, Academic Unit of Electrical Engineering, Paraíba State, Brazil \\ e MRE Engenharia (Electromagnetic Radiations Measurement-Engineering), Belo Horizonte City, Minas Gerais State, Brazil \\ ${ }^{\mathrm{f}}$ Faculty of Medical Sciences, Medicine-Belo Horizonte, Belo Horizonte City, Minas Gerais State, Brazil \\ ' UFMG-Universidade Federal de Minas Gerais-Belo Horizonte, Urban Health Observatory, Belo Horizonte City, Minas Gerais State, Brazil
}

\section{A R T I C L E I N F O}

Article history:

Received 14 January 2011

Received in revised form 25 May 2011

Accepted 25 May 2011

Available online 13 July 2011

\section{Keywords:}

Assessment and management of impacts and environmental risks

Non-ionizing electromagnetic radiation

Public health

Radio base station

Environmental electromagnetic pollution

Environmental electromagnetic

field monitoring

\begin{abstract}
A B S T R A C T
BS = cellular antenna Base station

Pollution caused by the electromagnetic fields (EMFs) of radio frequencies (RF) generated by the telecommunication system is one of the greatest environmental problems of the twentieth century. The purpose of this research was to verify the existence of a spatial correlation between base station (BS) clusters and cases of deaths by neoplasia in the Belo Horizonte municipality, Minas Gerais state, Brazil, from 1996 to 2006 and to measure the human exposure levels to EMF where there is a major concentration of cellular telephone transmitter antennas. A descriptive spatial analysis of the BSs and the cases of death by neoplasia identified in the municipality was performed through an ecological-epidemiological approach, using georeferencing. The database employed in the survey was composed of three data banks: 1 . death by neoplasia documented by the Health Municipal Department; 2. BSs documented in ANATEL ("Agência Nacional de Telecomunicações": 'Telecommunications National Agency'); and 3. census and demographic city population data obtained from official archives provided by IBGE ("Instituto Brasileiro de Geografia e Estatística": "Brazilian Institute of Geography and Statistics'). The results show that approximately 856 BSs were installed through December 2006. Most (39.60\%) of the BSs were located in the "Centro-Sul" ('Central-Southern') region of the municipality. Between 1996 and 2006, 7191 deaths by neoplasia occurred and within an area of $500 \mathrm{~m}$ from the BS, the mortality rate was 34.76 per 10,000 inhabitants. Outside of this area, a decrease in the number of deaths by neoplasia occurred. The greatest accumulated incidence was 5.83 per 1000 in the Central-Southern region and the lowest incidence was 2.05 per 1000 in the Barreiro region. During the environmental monitoring, the largest accumulated electric field measured was $12.4 \mathrm{~V} / \mathrm{m}$ and the smallest was $0.4 \mathrm{~V} / \mathrm{m}$. The largest density power was $40.78 \mu \mathrm{W} / \mathrm{cm}^{2}$, and the smallest was $0.04 \mu \mathrm{W} / \mathrm{cm}^{2}$.
\end{abstract}

(c) 2011 Elsevier B.V. All rights reserved.

\section{Introduction}

Mobile phone radio base stations (RBSs) are now found in cities and communities worldwide. They can be found near or even on top of homes, schools, hospitals, daycare centers and offices. In Brazil, the number of mobile phone users is estimated to be over 200 million and there are more than 5 billion users worldwide. In the municipality of Belo Horizonte, the capital of the state of Minas Gerais, there are approximately 1000 base stations (BSs) with 128.77 accesses by

\footnotetext{
is All the authors declare that they have no conflicts of interest.

* Corresponding author at: Rua Desembargador Assis Rocha, 279, Bairro Belvedere, 30320-250, Belo Horizonte (MG), Brazil. Tel.: +55 03132861892.

E-mail addresses: adilzadode@terra.com.br (A.C. Dode), monica@desa.ufmg.br (M.M.D. Leão).
}

mobile phones per 100 inhabitants and in Brazil, there are 49,979 BSs licensed through April 2011 (ANATEL, 2011).

The non-ionizing electromagnetic radiation from the BSs is of low intensity compared to the current guidelines on human exposure limits. However, its emission is continuous. This raises concerns as to whether the health and well-being of people living or working close to the BSs are at risk Khurana et al., 2010; Alanko et al., 2008.

The emission of a BS is usually described by its effectively radiated power in watts $(\mathrm{W})$, which describes the total amount of radiation emitted by the antenna of the BS. Their intensity, called the power density, is commonly measured in milliwatts per square centimeter $\left(\mathrm{mW} / \mathrm{cm}^{2}\right)$ or microwatt per square centimeter $\left(\mu \mathrm{W} / \mathrm{cm}^{2}\right)$ and it expresses the power per unit area impinging normally to the external surface of the subject. The immission (absorption) of the subject is measured by the specific absorption rate (SAR), which is reported in 
watts per kilogram of body tissue $(\mathrm{W} / \mathrm{kg})$. The SAR reflects the power that is locally absorbed in a certain volume of biological tissue and is proportional to the square of the local magnitude of the electric field intensity. For ethical reasons, the SAR can only be assessed on animal models or inferred from virtual (computational) models of animal or human subjects (Lai, 2000).

Some scientific studies have shown evidence of increased numbers of cancer cases for people living less than $500 \mathrm{~m}$ from the BSs (Eger et al., 2004; Wolf and Wolf, 2004; Eger and Jahn, 2010).

In the Belo Horizonte municipality and in many other urbanized cities and communities in Brazil, the mobile phone network is deployed in regions of high demographic density close to homes and on the facades and roofs of public or private buildings. It is also common to have several antennas sharing the same support structure.

This situation motivated the research of Dode (Dode, 2003) in the Belo Horizonte municipality, where a methodology designed to assess the levels of electromagnetic radiation exposure of the dwellers was used, based on the technical specifications of a sample of the installed BSs. Those estimated data were then compared to measured in situ data for the same set of BSs. Fig. 1 illustrates the site of a typical BS (Base Station BH 20) in a residential area of the Serra neighborhood, in the Belo Horizonte municipality and Fig. 2 shows its geographical location. Fig. 3 represents the horizontal and vertical radiation patterns per sector of the same BS. This diagram has been obtained from the technical archives documented by the operators in the Secretaria Municipal de Meio Ambiente (Municipal Environmental Department), the official organization of the municipality that is responsible for the environmental licensing of the BSs.

Some studies have shown evidence of general risks to health and specific risks of cancer associated with the physical proximity of the transmitter antennas of the telecommunication network.

One of the first of these studies indicated an association between cancer growth and a residence near a transmitter antenna (Cherry, 1999). Later, Santini et al. (Santini et al., 2002) carried out a qualitative survey of 530 people living within $300 \mathrm{~m}$ of a certain BS. Despite the subjective methodology, the study showed a peak of symptoms occurred at locations in the interval between 50 and $100 \mathrm{~m}$ from the $\mathrm{BS}$, which coincided with the typical distances at which the main lobe reached the ground. In another study, also in France, Santini et al. (2003) surveyed dwellers living $300 \mathrm{~m}$ from the BS and others who lived farther away and found more complaints about irritability, depressive tendency, memory loss, problems with concentration, dizziness, within $100 \mathrm{~m}$; headache, sleeping disorder, discomfort, skin problem within $200 \mathrm{~m}$; and fatigue within $300 \mathrm{~m}$, among those living closer to the BS and showed more variability in disease occurrence with distance. Again, this study contained some biases because it was subjective and therefore did not result in a conclusion about the relationship between cancer and the amount of radiation exposure.

Navarro et al. (2003) conducted a study of 145 people in Múrcia, Spain, but only included 101 questionnaires in the analysis. Two groups of participants were formed: one that was living within $150 \mathrm{~m}$ of the BS and another beyond $150 \mathrm{~m}$. The average measured power density was $1.1 \mu \mathrm{W} / \mathrm{cm}^{2}$ at locations within $150 \mathrm{~m}$ and $0.1 \mu \mathrm{W} / \mathrm{cm}^{2}$ beyond $150 \mathrm{~m}$. This study also showed that complaints (insomnia, headaches, difficulty in concentration, discomfort) were greater at locations where the power density was higher, inside the $150 \mathrm{~m}$ range.

In Poland, Gadzicka (Gadzicka et al., 2006) also used a questionnaire to conduct a neurobehavioral clinical study involving 500 subjects. The most important finding was the incidence of frequent headaches in subjects living less than $150 \mathrm{~m}$ from the BS. However, the study was limited because of the lack of information about the technical characteristics of the BS and the measurements of electromagnetic exposure.

Eger et al. (2004) carried out research in the city of Naila, Germany, to examine whether people who live near mobile phone BSs were at any risk of becoming ill with malignant tumors. Their data bank consisted of records of patients from 1994 to 2004. While preserving the privacy of the information, the personal data of almost 1000 subjects were examined. The analysis showed that the number of newly developed cancer cases was significantly higher among those

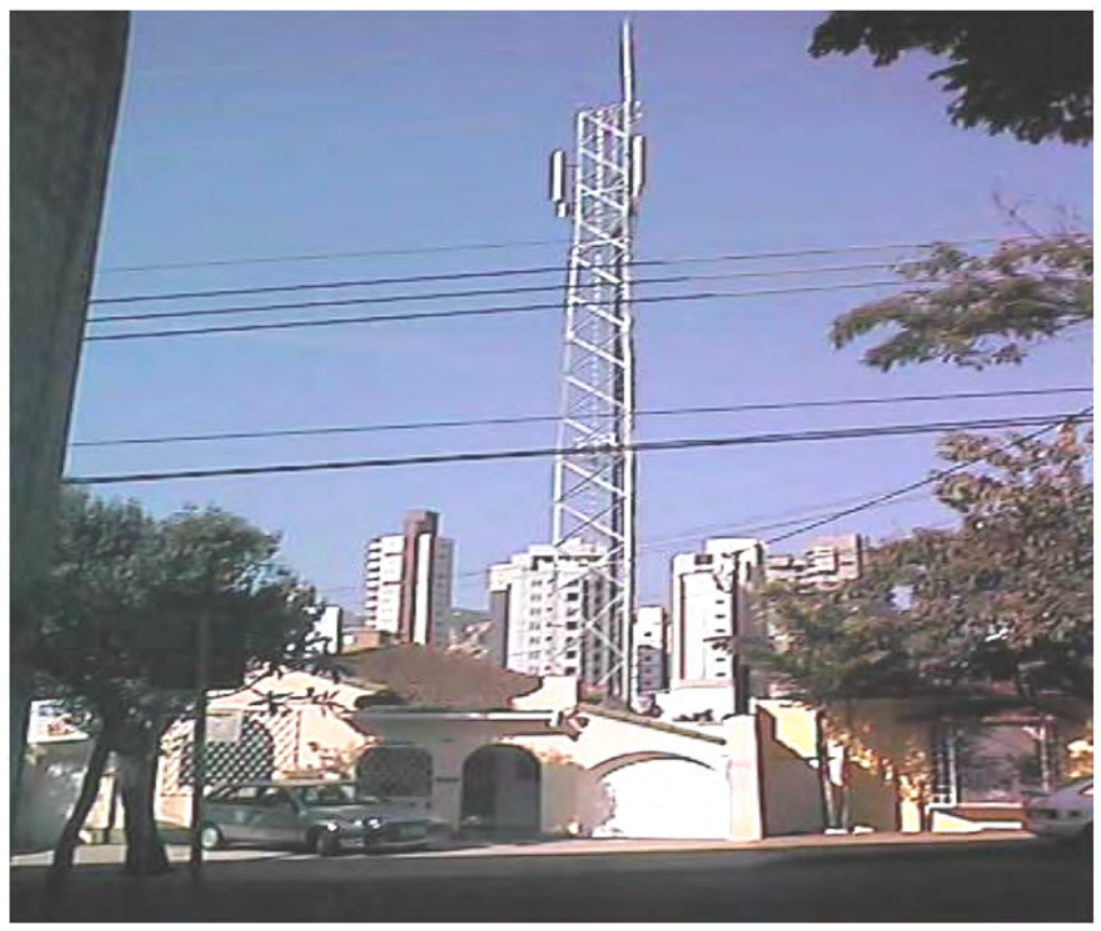

Fig. 1. BS site BH 20 in a residential area of the Serra neighborhood in Belo Horizonte municipality. 


\begin{tabular}{|l|l|}
\hline BS & Site BH 20 - Maxitel \\
\hline Address & $\begin{array}{l}1373 \text { Rua do Ouro Street - Bairro Serra neighborhood - Belo Horizonte } \\
\text { municipality }\end{array}$ \\
\hline Latitude & S $19^{\circ} 56^{\prime} 33,7^{\prime \prime}$ \\
\hline Longitude & W $43^{\circ} 55^{\prime} 8,7^{\prime \prime}$ \\
\hline
\end{tabular}

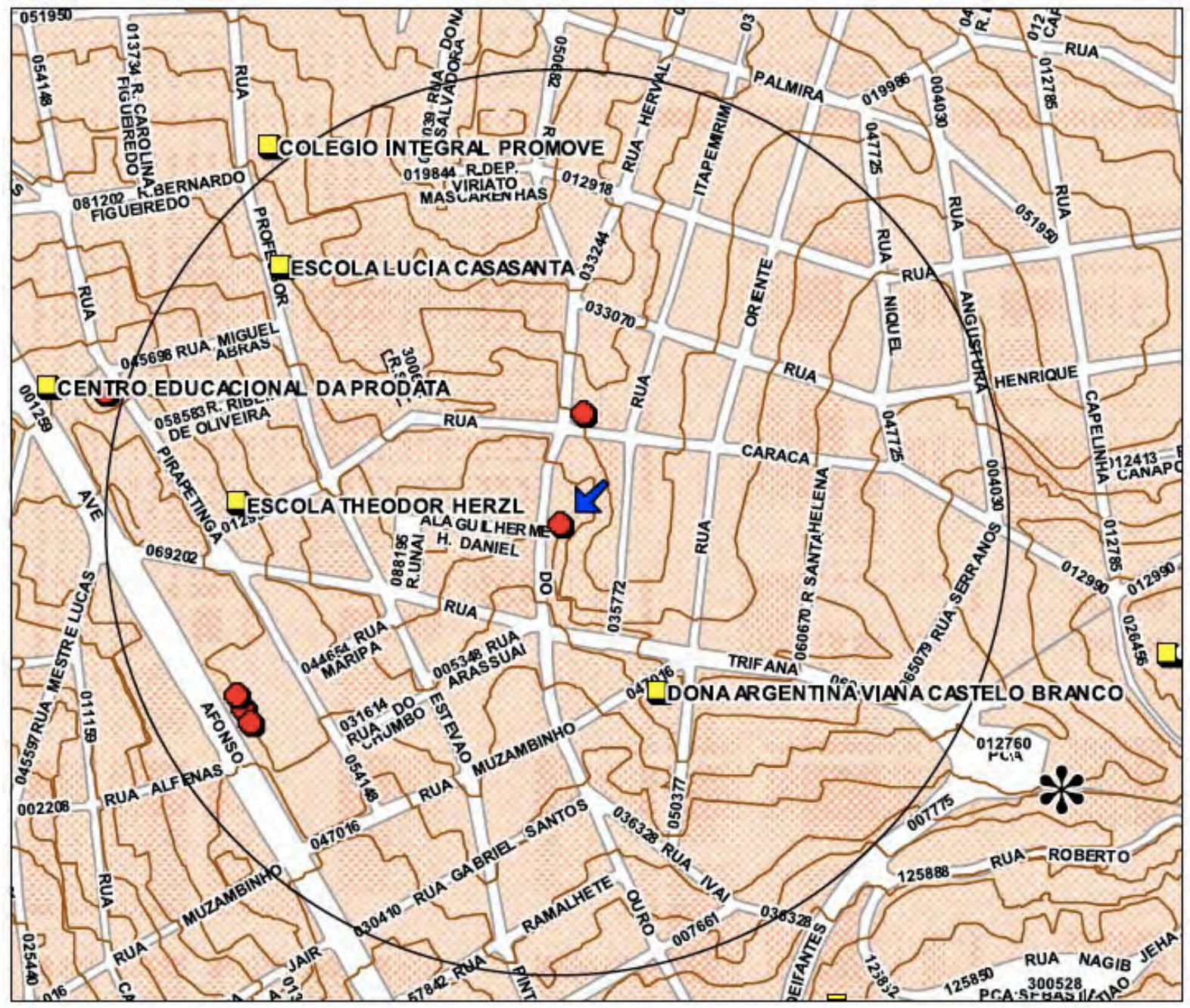

Fig. 2. Geographical location of BS Site BH 20 at 1373 Rua do Ouro Street, in the Serra neighborhood, Belo Horizonte municipality (Dode, 2003).

patients who had lived at distances within $400 \mathrm{~m}$ of the BS site, compared to the number of subjects who had lived beyond $400 \mathrm{~m}$ in the same period of time. The former subjects became sick eight years earlier, on average, than the latter subjects. The BS came into operation in 1993. From 1999 to 2004, that is, after five years' operation of the transmitting installation, the relative risk of suffering from cancer was three times higher for the subjects living within $400 \mathrm{~m}$ of the BS, compared to the dwellers beyond that distance. This study represents a milestone in the field because its results clearly demonstrate that the radiation from the BS may contribute to an increase in the clinical manifestation of the disease and the general development of cancer, even at exposure levels several orders of magnitude lower than the limits of the current guidelines.

Wolf and Wolf (2004) led a study in the town of Netanya, Israel, which showed an increase of 4.15 times in cancer incidence among subjects living within $350 \mathrm{~m}$ of the BS, compared to those who had lived further away. The total number of participants ( $n=622$, group A) were individuals who had lived for a duration of three to seven years near a mobile phone BS and were also patients of a health care clinic. The exposure took place one year before the beginning of the study, when the BS came into operation. A second group of individuals $(n=1222$, group B), who received medical care in a clinic near the BS and had environmental, socioeconomic and occupational characteristics similar to the first group was used as the control group. In group A, eight types of cancer had been diagnosed within a period of only one year. This rate was compared both to the rate of 31 cases per 10,000 people per year in the general population and the rate of two cases per 1222 people recorded in group B. A 95\% confidence interval to each rate was calculated and the rate of cancer occurrence in group A was found to be significantly higher than the rates of group $B$ and the entire population. The relative cancer rate was 10.5 among the exposed women of group A, 0.6 among the women of group B and 1.0 for the entire town of Netanya. Therefore, the cancer 


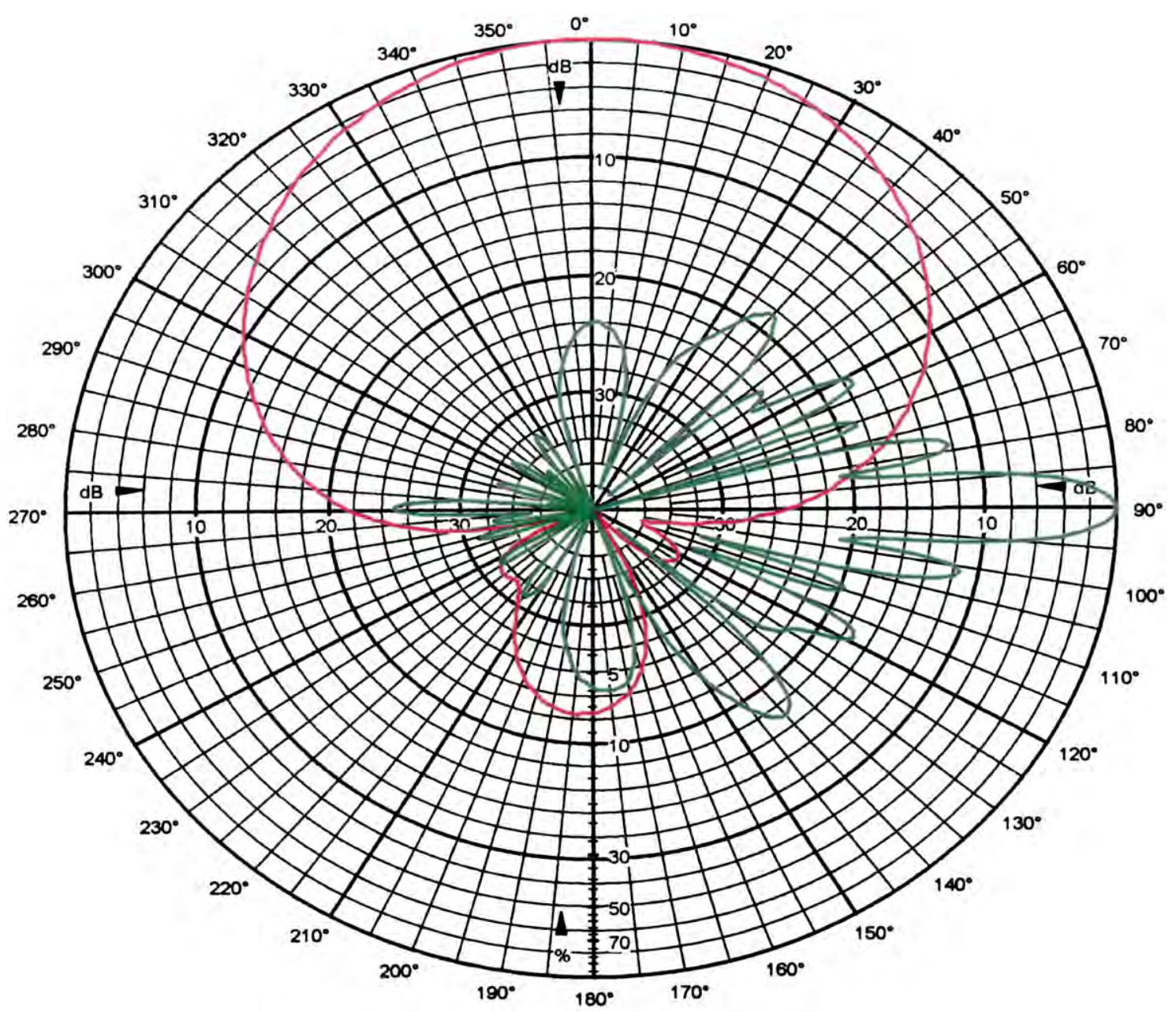

This is the pattern of a sector antenna. You need 4 for 360 degree spread.

\begin{tabular}{|l|l|l|l|}
\hline \multirow{2}{*}{ KIATH REDU } & $\begin{array}{l}\text { Date } \\
21.06 .1995\end{array}$ & $\begin{array}{l}\text { Type } \\
\text { Horizontal and Vertical } \\
\text { Radiation Patterns } \\
870 \mathrm{MHz}\end{array}$ & 737656 \\
\cline { 2 - 3 } & Name & \\
\hline
\end{tabular}

Fig. 3. Horizontal and vertical radiation patterns per sector of BS site BH 20 (KATHREIN MOBILCOM BRASIL LTDA. HUEMER E. and LENSIG Kl-, 1999).

incidence in the women of group A was significantly higher $(\mathrm{p}<0.0001)$ than the cancer incidence of group $B$ and the city as a whole. A relative risk comparison revealed that there were approximately 4.15 more cases of cancer in group A than in the population as a whole. The results, although still not conclusive, indicated a necessity to revise the current exposure limits in favor of more protective levels. Both the estimated and measured power densities in the entire exposed area in Netanya were far below $0.53 \mu \mathrm{W} / \mathrm{cm}^{2}$, that is, approximately 800 times lower than the exposure limit of $425 \mu \mathrm{W} / \mathrm{cm}^{2}$ for the frequency of $850 \mathrm{MHz}$ from the ICNIRP guidelines.

The aforementioned studies, which aimed to find evidences of an increase in cancer incidence with proximity to mobile phone BSs, warrant additional research, because the cellular phone technology is relatively new and the associated total amount of environmental radiation is far from negligible.

The inhabitants of the Belo Horizonte municipality and the scientific community in general are also concerned about the number of already installed BSs and the proliferation of new wireless BSs, not only for telephony but also for television. The number of mobile phone BSs, which equaled 474 in 2003, had reached approximately 856 in 2006.

Thus, this research to study health was conducted in a broad environmental context, aiming to verify if there is a spatial correlation between the cellular telephony system BS location and the cases of death by neoplasia during the period between 1996 and 2006.

\section{Materials and methods}

\subsection{Area of study}

The Belo Horizonte municipality, with an area of approximately $300 \mathrm{~km}^{2}$ of area, has a tropical climate and is located at an average altitude of $900 \mathrm{~m}$ (minimum of $800 \mathrm{~m}$ and maximum of $1200 \mathrm{~m}$ ) 


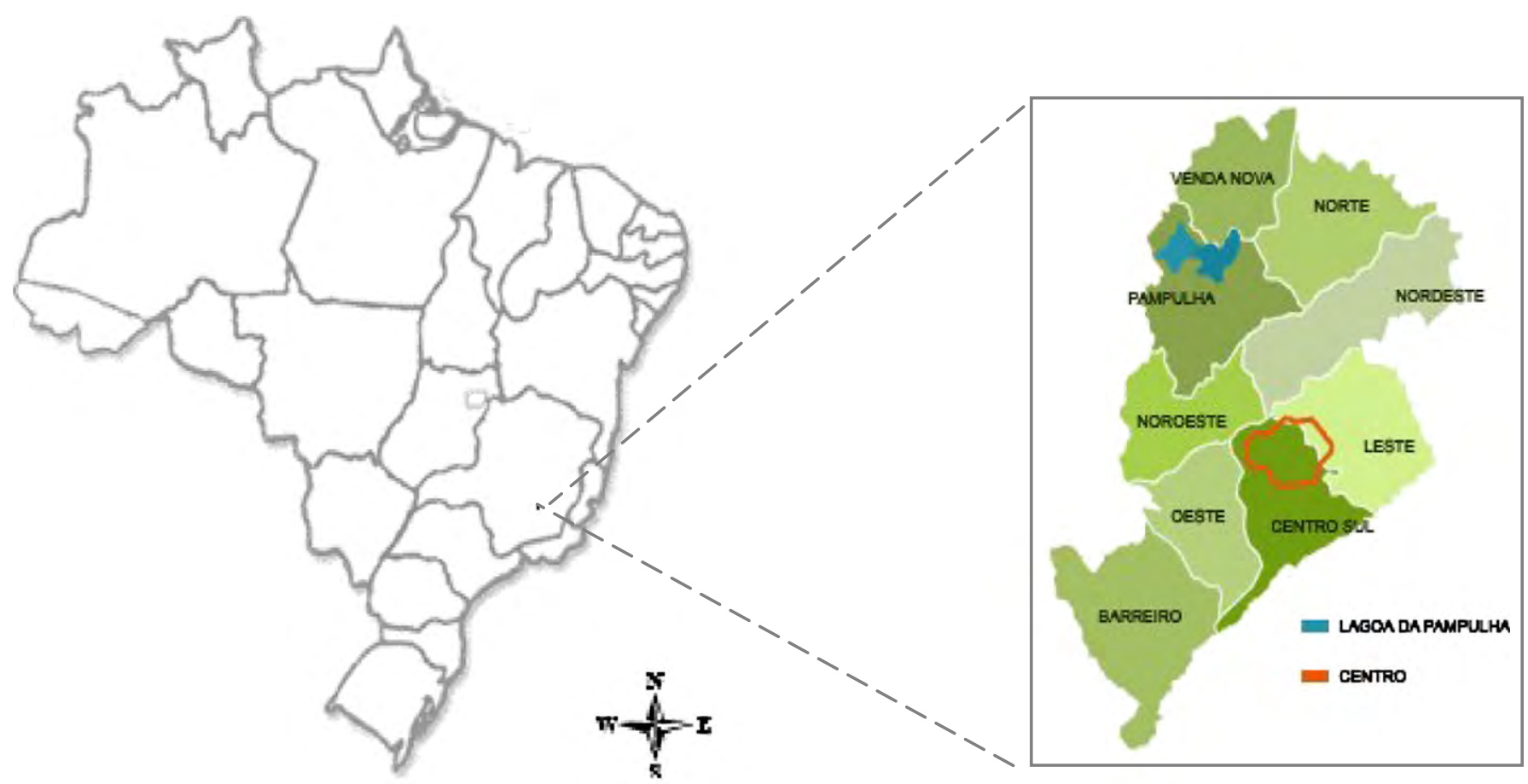

Fig. 4. The Belo Horizonte municipality and the nine SDs.

above sea level. The geology of the city includes several kinds of minerals and its soil of crystalline rocks is composed of dolomite, quartzite, phyllite and various schists. Constructed over many hills, the city is surrounded by a mountain named "Serra do Curral". The municipality is divided into nine regions or sanitary and administrative districts (SDs): "Centro-Sul" ("Central-Southern"), "Norte" ("Northern”), "Leste" (“Eastern"), "Oeste" ("Western"), "Noroeste" ("Northwestern"), "Nordeste" ("Northeastern”), "Venda Nova", "Pampulha" and "Barreiro". Fig. 4 shows the Belo Horizonte municipality and the nine SDs.

The municipality has 55 universities and colleges, 36 hospitals, and a subway system containing 19 stations and $29 \mathrm{~km}$ of track, which transports 145,000 passengers a day. The majority of households are served by potable water (99.3\%), garbage collection (96.6\%), sewage (93.2\%), electric power (99.83\%), and landline phones $(81.43 \%)$ (UNDP, 2008) and 128.77 accesses by mobile phones per 100 inhabitants through April 2011 (ANATEL, 2011). With these data, one can conclude that much of the population possesses a cellular phone and more than $28 \%$ of the inhabitants have more than one. The city has road and railroad networks that link it to the main centers of the country, as well as three airports.

More than $80 \%$ of the municipal economy is focused on commerce, financial services, real estate activities and public administration. The metallurgical industries, including iron and steel metallurgy, and ore mining are located in the areas surrounding the metropolitan region but not in the Central-Southern region.

The city of Belo Horizonte has been selected by the Population Crisis Committee of the United Nations (UN, 2007) as the metropolis with the best quality of life in Latin America and was ranked 45th in the world. Its health system is considered very good, according to the Atlas of Human Development (2000)/United Nations Development Programme (UNDP, 2008).

The city had 2,238,332 inhabitants in 2003 and 2,258,096 in 2010 (IBGE, 2010), which suggests that the population in the city is stable. However, the city, as in any urban area in Brazil, has a concentrated population, with a large number of people living in apartment buildings. This fact, along with the mountainous landscape, force mobile phone operators to install their BSs at strategic points in the city, mainly on top of towers and poles, as on the terraces of public or residential buildings, to ensure good coverage of the mobile phone network.

Of the nine SDs, the Central-Southern region is the richest region of the city and is the third largest in number of inhabitants with 249,862. There are plenty of commercial and service shops, several shopping centers, and many households with one or more families. This SD also has several hospitals, parks and leisure areas. Most of the dwellers are highly educated and belong to the middle and upper classes. The traffic is heavy because of the large number of vehicles that travel in that region. The Western region is less densely populated, has no skyscrapers and its inhabitants have low revenues. The Barreiro region is the most populated after the Central-Southern SD, and has many industries. The most populated region, with 338,753 inhabitants, is the Northwestern (IBGE, 2000).

\subsection{Study design}

This ecological study consists of an exploratory spatiotemporal analysis to determine whether there is an association between clusters of BSs and deaths by neoplasia in the Belo Horizonte municipality, in the southeastern part of Brazil. This design was chosen because of the possibility of using geographic areas as units of analysis, where each unit of analysis is composed of a group of individuals or communities. Therefore, it is possible to determine whether there is a correlation between a certain risk and the occurrence of certain grievances within the population. In this type of study, it is not possible to consider individual characteristics, such as food and life habits, activity level, smoking, self-medication, individual pathologies, or genetic factors (GORDIS, 2004).

The analysis was based on the following databases: 1 . A database of deaths by neoplasia documented in the Mortality Information 
System (SIM: “Sistema de Informação em Mortalidade"), provided by the City Health Department; 2. A database of the site register of BSs, provided by the Brazilian Telecommunications Agency (ANATEL); 3. A database of the city census, including demographic information provided by the Brazilian Institute of Geography and Statistics (IBGE).

The death, BS and population data were geocoded according to census tracts (CTs) or censitarian sectors (CSs), which are "territorial units defined by IBGE (IBGE, 2000) to orient the spatial distribution of a population". The definition of a CT is related to a specific geographical zone whose population can be counted by local interviewers, taking into account the existence of geographical barriers, the population size and traffic flow. There were a total of 2563 CTs in the Belo Horizonte municipality (IBGE, 2000).

\subsubsection{Cancer death variable}

The main outcome that was studied was the number of deaths by neoplasia of Belo Horizonte municipality residents that occurred from 1996 to 2006, were reported to the City Health Department and were routinely confirmed by established criteria, under the responsibility of

Table 1

International classification of diseases - ICD-10.

\begin{tabular}{|c|c|c|c|}
\hline \multirow[t]{2}{*}{ Disease } & \multicolumn{2}{|c|}{ ICD-10 - According to WHO ICD10 homepage } & \multirow[t]{2}{*}{ Bibliographical references } \\
\hline & Primary & Secondary & \\
\hline $\begin{array}{l}\text { Primary: Malignant melanoma of skin; Other } \\
\text { malignant neoplasms of skin./Secondary } \\
\text { malignant neoplasm of skin. }\end{array}$ & C43 and C44 & C79.2 & Eger et al., 2004. \\
\hline $\begin{array}{l}\text { Primary: Malignant neoplasm of } \\
\text { breast./Secondary malignant } \\
\text { neoplasm of other specified sites. }\end{array}$ & C50 & C79.8 & $\begin{array}{l}\text { Eger et al., 2004; Wolf and Wolf, 2004; Bioinitiative } \\
\text { Report, 2007; Guenel et al., 1996; Feychting et al., } \\
\text { 1997; Wakeford, 2004; Mack et al., } \\
\text { 1991; Beall et al., 1996; Beniashvili et al., 2005; } \\
\text { Hardell and Sage, 2007. }\end{array}$ \\
\hline $\begin{array}{l}\text { Primary and secondary: Malignant neoplasm } \\
\text { without specification of site. }\end{array}$ & $\mathrm{C} 80$ & $\mathrm{C} 80$ & $\begin{array}{l}\text { Khurana, 2008; Hardell et al., 2007; Bioinitiative } \\
\text { Report, 2007; Mack et al., 1991; Beall et al., 1996; } \\
\text { Guenel et al., 1996; Wakeford, } 2004 .\end{array}$ \\
\hline $\begin{array}{l}\text { Primary: Malignant neoplasm of ovary./Secondary } \\
\text { malignant neoplasm of ovary. }\end{array}$ & C56 & C79.6 & Eger et al., 2004; Wolf and Wolf, 2004 \\
\hline $\begin{array}{l}\text { Primary: Hodgkin's Disease/Secondary and unspecified } \\
\text { malignant neoplasm of lymph nodes. }\end{array}$ & $\mathrm{C} 81$ & $\mathrm{C} 77$ & Wolf and Wolf, 2004. \\
\hline $\begin{array}{l}\text { Primary: Malignant neoplasm of bronchus and } \\
\text { lung/Secondary malignant neoplasm of lung }\end{array}$ & C34 & C78.0 & Eger et al., 2004; Wolf and Wolf, 2004 \\
\hline $\begin{array}{l}\text { Primary: Malignant neoplasm of kidney, except renal } \\
\text { pelvis./Secondary malignant neoplasm of other sites. }\end{array}$ & C64 & C79.0 & Wolf and Wolf, 2004. \\
\hline $\begin{array}{l}\text { Primary: Malignant neoplasm of prostate./Secondary } \\
\text { malignant neoplasm of other specified sites. }\end{array}$ & C61 & C79.8 & Eger et al., 2004. \\
\hline $\begin{array}{l}\text { Primary: Malignant neoplasm of pancreas; Pancreas, } \\
\text { unspecified./Secondary malignant neoplasm of } \\
\text { other and unspecified digestive organs. }\end{array}$ & C25 and C25.9 & C78.8 & Eger et al., 2004. \\
\hline $\begin{array}{l}\text { Primary: Malignant neoplasm of other and ill-defined } \\
\text { digestive organs: Intestinal tract, part unspecified; } \\
\text { Malignant neoplasm of small intestine; Malignant } \\
\text { neoplasm of colon; Malignant neoplasm of } \\
\text { rectosigmoid junction./Secondary malignant } \\
\text { neoplasm of small intestine; Secondary malignant } \\
\text { neoplasm of large intestine and rectum. }\end{array}$ & C26.0; C17; C18; C19 & C78.4; C78.5 & Eger et al., 2004. \\
\hline $\begin{array}{l}\text { Primary: Malignant melanoma of skin; Melanoma } \\
\text { in situ./Secondary malignant neoplasm of skin }\end{array}$ & C43 and D03 & C79.2 & Eger et al., 2004; Hallberg, 2004; Johansson, 2006. \\
\hline $\begin{array}{l}\text { Primary: Malignant melanoma of skin./Secondary } \\
\text { malignant neoplasm of skin. }\end{array}$ & C43 & C79.2 & Stang, 2001. \\
\hline $\begin{array}{l}\text { Primary: Malignant neoplasm of kidney, except renal } \\
\text { pelvis; Malignant neoplasm of renal } \\
\text { pelvis./Secondary malignant neoplasm of kidney and } \\
\text { renal pelvis. }\end{array}$ & C64 and C65 & C79.0 & Eger et al., 2004. \\
\hline $\begin{array}{l}\text { Primary: Malignant neoplasm of stomach./Secondary } \\
\text { malignant neoplasm of other and unspecified } \\
\text { digestive organs. }\end{array}$ & C16 & C78.8 & Eger et al., 2004. \\
\hline $\begin{array}{l}\text { Primary: Malignant neoplasm of bladder./Secondary } \\
\text { malignant neoplasm of bladder and other and } \\
\text { unspecified urinary organs. }\end{array}$ & C67 & C79.1 & Eger et al., 2004. \\
\hline $\begin{array}{l}\text { Primary: Multiple myeloma and malignant plasma cell } \\
\text { neoplasms; Lymphoid leukemia; Myeloid leukaemia; } \\
\text { Monocytic leukemia; Other leukemias of specified cell } \\
\text { type; Leukemia of unspecified cell type; Other and } \\
\text { unspecified malignant neoplasms of lymphoid, } \\
\text { haematopoietic and related tissue. }\end{array}$ & $\begin{array}{l}\text { C90; C91; C92; C93; } \\
\text { C94; C95 and C96 }\end{array}$ & & Eger et al., 2004. \\
\hline $\begin{array}{l}\text { Primary: Hodgkin's disease; Follicular [nodular] } \\
\text { non-Hodgkin's lymphoma; Diffuse } \\
\text { non-Hodgkin's lymphoma; Peripheral and } \\
\text { cutaneous T-cell lymphomas; Other and unspecified } \\
\text { types of non-Hodgkin's lymphoma./Secondary and } \\
\text { unspecified malignant neoplasm of lymph nodes. }\end{array}$ & C81; C82; C83; C84 and C85 & $\mathrm{C} 77$ & Hardell et al., 2007. \\
\hline $\begin{array}{l}\text { Primary: Malignant neoplasm of brain./Secondary } \\
\text { malignant neoplasm of brain and cerebral meninges. }\end{array}$ & C71 & C79.3 & $\begin{array}{l}\text { Khurana, 2008; Hardell et al., 2007; } \\
\text { Schoemaker et al., } 2005 .\end{array}$ \\
\hline
\end{tabular}


the epidemiology officers of the city, accredited by federal and local health authorities (BRAZIL, 2011).

All deaths by neoplasia, based on death certificates, were provided. Then, they were re-selected according to a subset of the International Classification of Diseases (ICD) previously organized and extracted from a careful review of the scientific literature, linking cancer and non-ionizing electromagnetic radiation, as can be seen in Table 1.

Out of 22,493 deaths that occurred in the analyzed period (1996 to 2006), 7191 were initially eligible for the study. The selected death by neoplasia cases were grouped according to the $\mathrm{CT}$ of the residences, based on the residents' postal address. The data bank of SIM did not possess the address of the persons who died by neoplasia in 1998. So, about 780 deaths that occurred in that year could not be georeferenced. To identify the CT, the cartographic map was used, within the borders delimited by IBGE (IBGE, 2000). Fig. 5 shows the fluxogram of deaths by neoplasia in the period from 1996 to 2006.

The death cases were further analyzed according to age, gender, site of residence and year of occurrence and the death rates were determined as described below. After aggregation of the deaths and BS exposure (explained below) in the CT, differing numbers of deaths were determined, depending on whether the date of first exposure was taken to be the date of the first license of the BS (7191 deaths) or the date of the register of the BS (8082 deaths). We opted to work with the date of first license; an option that makes our analysis even more conservative.

\subsubsection{Base stations}

The BS database and their respective geographical locations were obtained from the ANATEL database (site: http://www.anatel.gov.br) and were further geoprocessed according to their CT in two distinct years: 2003 and 2006. In 2003, there were approximately 474 BSs, and in 2006, there were approximately 856 in the city. Clusters (the socalled "hotspots") were the identified in each SD. This explanatory analysis was carried out through thematic maps, using the software

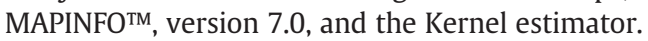

\subsubsection{Data processing and mapping of the BSs and deaths in the Belo} Horizonte municipality

Eligible deaths by neoplasia were then plotted inside circles with radii varying from $100 \mathrm{~m}$ to $1000 \mathrm{~m}$, centered at the location of the first transmitter antenna of the mobile phone network to which the resident was possibly exposed. This selection took into account the date of the death and either the date of registration or of the first

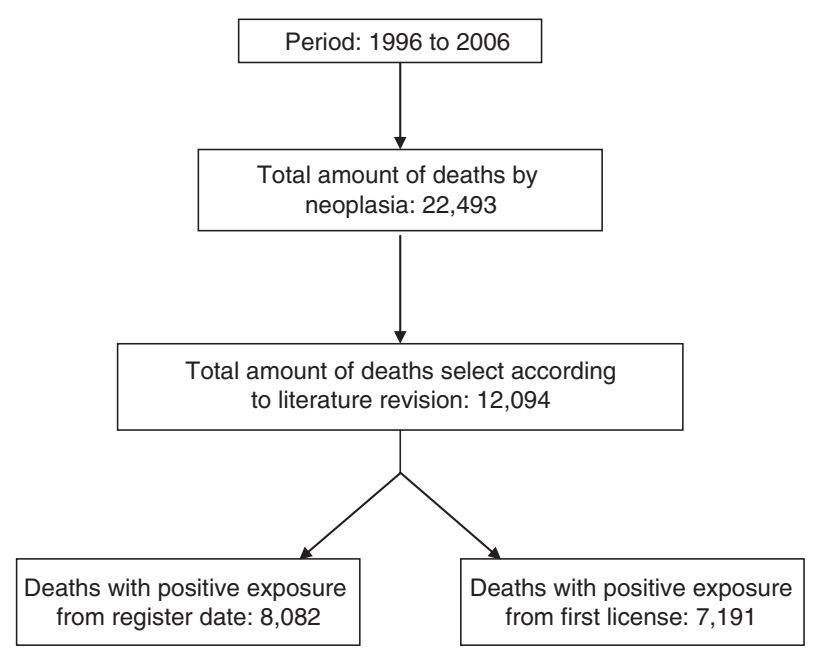

Fig. 5. Fluxogram of deaths by neoplasia in the period from 1996 to 2006. license of the given BS. To detect case conglomerates in space, the total amount (2563) of CTs and the corresponding nine DSs of the city were used again. Software was developed to calculate the shortest distance between the death and the antenna and to estimate the time of exposure of the deaths to the radiation of the antennas.

\subsubsection{Death rates}

The mortality by neoplasia rates per CT were determined from the neoplasia diagnoses in compliance with the ICD-10 during the period of the study, using the CT as defined by IBGE for the 2000 national census as the spatial analysis unit. The deaths in every CT were used as the numerator. The temporal unit was the calendar year. The death data were then georeferenced to the address of the subject's and the IBGE census data (IBGE, 2000) for each CT. The estimated population at risk was used as the denominator.

The accumulated incidence in the Belo Horizonte municipality was calculated by dividing the total amount of deaths in each region by region's entire population.

\subsubsection{Estimates of the mortality rates according to distance and duration of exposure to the radiation of the $B S s$}

To understand the spatiotemporal exposure to the radiation of the BSs, the duration of possible exposure corresponding to each death was estimated, using a proxy to the subject's residential addresses, in terms of the duration of his or her exposure to the first installed transmitter antenna of the mobile phone network. To estimate the number of days of exposure, the elapsed time period from the date of installation of the first antenna to the date of the death was calculated, in spite of the exposure to the radiation of other antennas that might have been installed afterward. Some subjects may have been exposed to many antennas at different times, but in this study we considered only the date of installation of the first antenna. The delimitation of the distance intervals of the BSs was then performed. Each interval with a radius of $100 \mathrm{~m}$ had a BS as its center, from which the distance was increased to $1000 \mathrm{~m}$. For each 100-meter interval, the deaths that occurred within the elapsed period of time, as well as the estimated population living within that radius, was then observed. To obtain the population at risk, the estimates of all of the CTs were considered, even those which were only partially included within those radii. Therefore, the population at risk was conservatively overestimated.

To estimate the mortality rate within each radius, the number of deaths was divided by the estimated population included in the radius of each CT. For example, for the 100-meter radius, the 3569 deaths were divided by the 821,890 estimated exposed subjects living inside that radius. For the rates between $200 \mathrm{~m}$ and $1000 \mathrm{~m}$, both the number of deaths and the included population were cumulatively considered. This was necessary because the subjects included in the 100 -meter radius must be considered to perform the calculation inside the 200-meter radius (Fig. 6) (Table 5).

\subsection{Environmental monitoring of the electromagnetic field (EMF)}

In 2008, one began monitoring the environmental EMF in the CT with the largest concentration of antennas in the Belo Horizonte municipality. The survey used an electric field meter and isotropic probe, with a frequency range of $0.2 \mathrm{MHz}$ to $3.0 \mathrm{GHz}$; a spectrum analyzer, with a frequency range of $10.0 \mathrm{MHz}$ to $6.0 \mathrm{GHz}$; a datalogging multimeter; a GPS unit and a laptop. For the field measurements, the following guidelines were observed: IEEE, 1999, 1992; NCRP, 1993; ANATEL Annex to Resolution no. 303 (ANATEL, 2000a, 2000b), and the environmental field survey of two particular nearby BSs, carried out by Dode (Dode, 2003). The analyzed frequencies of the BSs were corresponded to the bands A, B, C and D. During the measurements, stronger electric field intensities were usually found when the probe was far from the ground. Approximately 400 points in the Central-Southern 


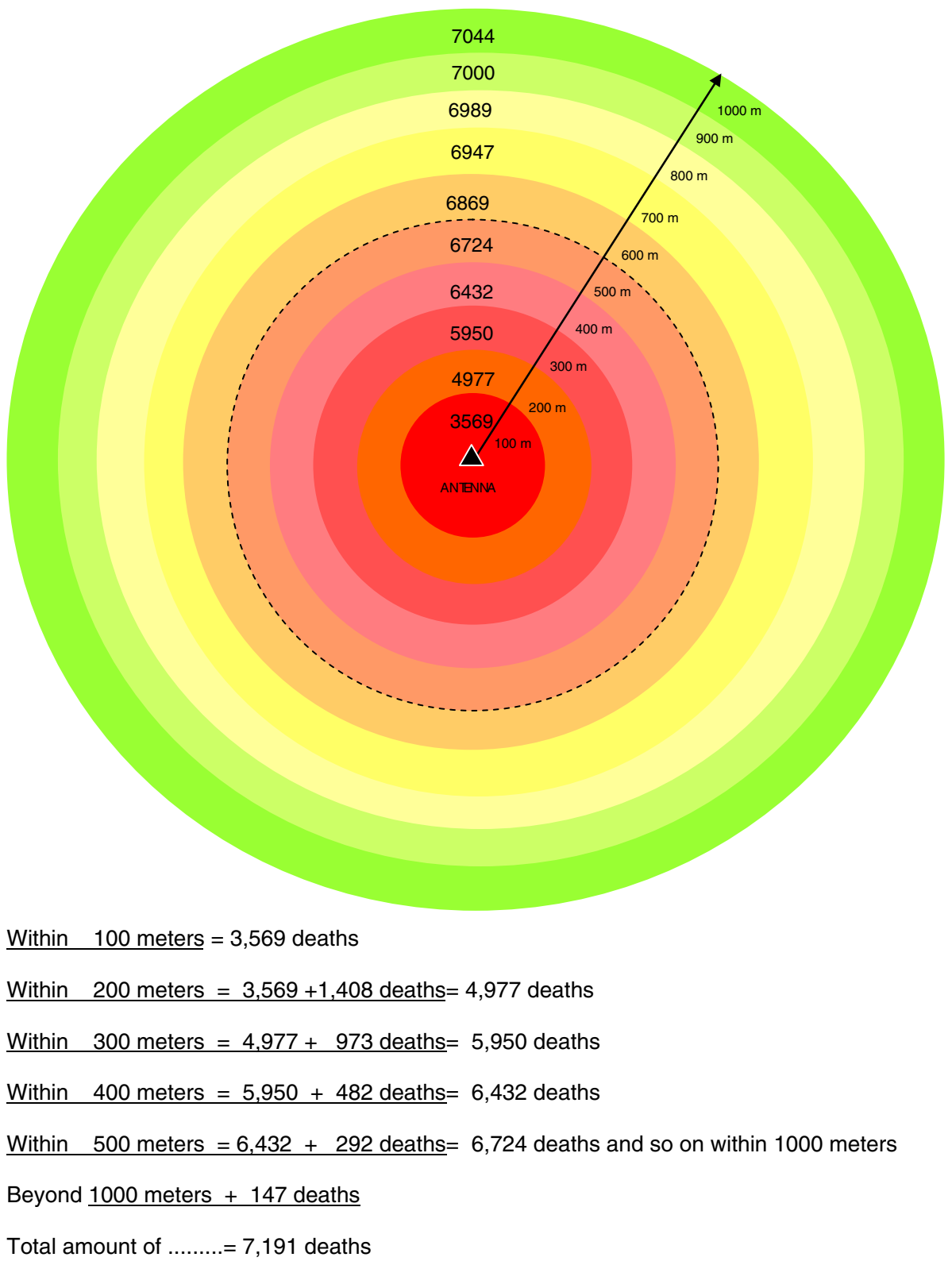

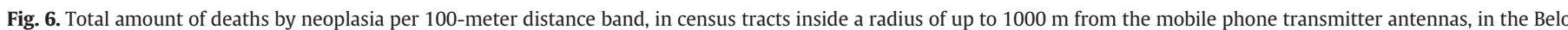
Horizonte municipality, from 1996 to 2006. Total: 7044 deaths.

region of the municipality, which were located in squares, parks, schools and households nearby BSs, were considered in the survey.

\subsection{Ethical committees}

Because this study includes data on human beings, it was approved by the ethical committees of the Institutional Review Boards of the Federal University of Minas Gerais and the Belo Horizonte City Health Department, with the purpose of accomplishing the Resolution 196/1996 of the Brazilian Health Ministry.

\section{Results}

3.1. Total deaths by neoplasia selected in the period from 1996 to 2006

Fig. 7 shows the geographic location of the cases of deaths by neoplasia that were confirmed in the literature and selected according to Table 1, totaling 7191 deaths. The detailed geographic description of deaths location can be seen in Table 2. The Central-Southern SD contained the greatest absolute number of deaths, followed by the Northwestern and Eastern SDs.

\subsection{Base station}

All registered BSs that were georeferenced through 2006 are plotted in Fig. 8. The percentage of BSs installed through December 2003 was the greatest in the Central-Southern region, comprising 38.60\% (182 out of 474); until December 2006, the percentage was approximately $39.60 \%$ (338 out of 856). The BS percentage by region in the Belo Horizonte municipality in 2003 and 2006 can be seen in Fig. 9.

3.3. Data processing and mapping of the base stations and deaths in the Belo Horizonte municipality

Fig. 10 portrays a sample of the georeferencing of the BSs and the deaths by neoplasia in downtown Belo Horizonte City located 
Table 2

Description of the death coding and geographic location.

\begin{tabular}{|c|c|c|c|c|c|c|c|c|c|c|}
\hline \multirow{2}{*}{$\begin{array}{l}\text { Deaths } \\
\text { codification }\end{array}$} & \multicolumn{10}{|c|}{ Regions or sanitary districts } \\
\hline & Barreiro & Central-Southern & Eastern & Northeastern & Northwestern & Northern & Western & Pampulha & Venda Nova & Total \\
\hline C16 & 83 & 143 & 132 & 124 & 183 & 75 & 125 & 57 & 89 & 1011 \\
\hline $\mathrm{C} 17$ & 2 & 3 & 4 & 1 & 3 & 2 & 4 & 4 & 0 & 23 \\
\hline C18 & 1 & 2 & 2 & 2 & 1 & 1 & 3 & 0 & 1 & 13 \\
\hline C19 & 4 & 8 & 13 & 9 & 16 & 2 & 7 & 1 & 5 & 65 \\
\hline $\mathrm{C} 25$ & 30 & 155 & 88 & 74 & 137 & 23 & 77 & 42 & 39 & 665 \\
\hline $\mathrm{C} 26$ & 4 & 27 & 17 & 12 & 17 & 19 & 23 & 14 & 14 & 147 \\
\hline C34 & 88 & 300 & 194 & 140 & 233 & 89 & 187 & 75 & 99 & 1405 \\
\hline C43 & 0 & 0 & 0 & 0 & 0 & 0 & 0 & 0 & 1 & 1 \\
\hline C50 & 43 & 210 & 145 & 68 & 177 & 23 & 94 & 35 & 34 & 829 \\
\hline C61 & 42 & 174 & 131 & 84 & 186 & 51 & 122 & 56 & 58 & 904 \\
\hline C64 & 17 & 40 & 28 & 19 & 28 & 16 & 20 & 10 & 11 & 189 \\
\hline C65 & 0 & 1 & 0 & 1 & 0 & 0 & 1 & 0 & 3 & 6 \\
\hline C67 & 18 & 51 & 42 & 28 & 40 & 10 & 30 & 21 & 12 & 252 \\
\hline C71 & 37 & 105 & 54 & 37 & 94 & 23 & 63 & 30 & 28 & 471 \\
\hline C80 & 36 & 86 & 71 & 55 & 83 & 36 & 61 & 21 & 34 & 483 \\
\hline C81 & 5 & 19 & 8 & 4 & 9 & 3 & 9 & 3 & 5 & 65 \\
\hline C83 & 0 & 2 & 0 & 0 & 1 & 0 & 0 & 0 & 0 & 3 \\
\hline C84 & 0 & 0 & 0 & 0 & 0 & 0 & 1 & 0 & 0 & 1 \\
\hline C90 & 11 & 40 & 39 & 21 & 41 & 14 & 33 & 13 & 16 & 228 \\
\hline C91 & 4 & 11 & 6 & 10 & 12 & 3 & 15 & 7 & 7 & 75 \\
\hline C92 & 19 & 62 & 34 & 24 & 43 & 13 & 34 & 14 & 16 & 259 \\
\hline C93 & 0 & 1 & 0 & 0 & 1 & 0 & 0 & 0 & 1 & 3 \\
\hline C94 & 0 & 2 & 0 & 0 & 0 & 0 & 0 & 0 & 0 & 2 \\
\hline C95 & 7 & 17 & 10 & 4 & 18 & 7 & 12 & 4 & 12 & 91 \\
\hline Total & 451 & 1459 & 1018 & 717 & 1323 & 410 & 921 & 407 & 485 & 7191 \\
\hline
\end{tabular}

in Central-Southern region. A given BS can have three, six, nine, twelve or more antennas, depending on the requirements in the region.

To detect clusters of cases in space, the nine SDs in the Belo Horizonte and their 2563 CTs were used as units of analysis. In Fig. 11, there are CTs with 12,13, 14 and even 18 deaths.

Table 3

Percentage of deaths by age and gender in Belo Horizonte municipality.

\begin{tabular}{lrrcc}
\hline Age & Male & Female & Deaths total & Percentage\% \\
\hline $00-04$ & 10 & 16 & 26 & 0.36 \\
$05-09$ & 13 & 10 & 23 & 0.32 \\
$10-14$ & 12 & 8 & 20 & 0.28 \\
$15-19$ & 11 & 8 & 19 & 0.26 \\
$20-29$ & 34 & 34 & 68 & 0.95 \\
$30-39$ & 80 & 120 & 200 & 2.78 \\
$40-49$ & 247 & 322 & 569 & 7.91 \\
$50-59$ & 535 & 559 & 1,094 & 15.21 \\
$60-69$ & 920 & 686 & 1,606 & 22.33 \\
$70-79$ & 1,217 & 797 & 2,014 & 28.00 \\
$80-89$ & 708 & 550 & 1,258 & 17.49 \\
$90-99$ & 136 & 158 & 294 & 4.08 \\
TOTAL & 3,923 & 3,268 & 7,191 & \\
\hline
\end{tabular}

Table 4

Accumulated incidence rate of all deaths in the Belo Horizonte municipality.

\begin{tabular}{lrrl}
\hline $\begin{array}{l}\text { Regions or sanitary } \\
\text { districts }\end{array}$ & Population & Death number & $\begin{array}{l}\text { Accumulated incidence } \\
\text { rate/1000 }\end{array}$ \\
\hline Centro-Sul & 249,862 & 1459 & 5.83 \\
Leste & 251,118 & 1018 & 4.05 \\
Noroeste & 338,753 & 1323 & 3.90 \\
Pampulha & 106,330 & 407 & 3.82 \\
Oeste & 249,059 & 921 & 3.69 \\
Nordeste & 248,406 & 717 & 2.88 \\
Norte & 153,821 & 410 & 2.66 \\
Venda Nova & 198,475 & 485 & 2.44 \\
Barreiro & 219,873 & 451 & 2.05 \\
TOTAL & $2,015,697$ & 7191 & \\
\hline
\end{tabular}

\subsection{Death rate}

The percentage of deaths by neoplasia per year in the Belo Horizonte municipality from 1996 to 2006, considering the start of exposure to be the date of the first license, is shown in Fig. 12. The accumulated incidence rate per 1000 residents for each SD is shown in Table 4. Again the Central-Southern SD presented the highest accumulated incidence rate, i.e., 5.83 incidents per 1000 inhabitants and the lowest rate was 2.05 incidents per 1000 inhabitants in the Barreiro SD.

The same trend was observed for both women and men with similar profiles during the studied years. As expected the incidence of death of women and men was higher in those older than 40 , and in this group, the number of deaths was 3923 for men and 3268 for women. After the age of 40 , the death rate $(7.91 \%)$ grew for both sexes, as shown in Table 3 . After the age of 60 , the rate was even higher (22.33\%).

Supplementary Graphics 1 shows the rate of death by neoplasia, according to ICD classification. The most significant causes were malignant neoplasm of bronchus and lung (C34), 19.55\%; malignant neoplasm of stomach (C16), 14.05\%; malignant neoplasm of prostrate

Table 5

Mortality rates by neoplasia in the Belo Horizonte municipality, according to distance from the BS.

\begin{tabular}{lccll}
\hline $\begin{array}{l}\text { Distance } \\
\text { (meters) }\end{array}$ & $\begin{array}{l}\text { Deaths } \\
\text { total }\end{array}$ & $\begin{array}{l}\text { Population } \\
\text { total }\end{array}$ & $\begin{array}{l}\text { Mortality rate/ } \\
10,000\end{array}$ & $\begin{array}{l}\text { Relative } \\
\text { risk }\end{array}$ \\
\hline Until 100 & 3569 & 821,890 & 43.42 & 1.35 \\
Until 200 & 4977 & $1,237,368$ & 40.22 & 1.25 \\
Until 300 & 5950 & $1,602,869$ & 37.12 & 1.15 \\
Until 400 & 6432 & $1,796,604$ & 35.80 & 1.11 \\
Until 500 & 6724 & $1,934,032$ & 34.76 & 1.08 \\
Until 600 & 6869 & $2,030,093$ & 33.83 & 1.05 \\
Until 700 & 6947 & $2,055,325$ & 33.80 & 1.05 \\
Until 800 & 6989 & $2,086,712$ & 33.49 & 1.04 \\
Until 900 & 7000 & $2,107,277$ & 33.21 & 1.03 \\
Until 1000 & 7044 & $2,148,327$ & 32.78 & 1.00 \\
Null hypothesis & 7,191 & $2,238,332$ & 32.12 & 1.00 \\
\hline
\end{tabular}




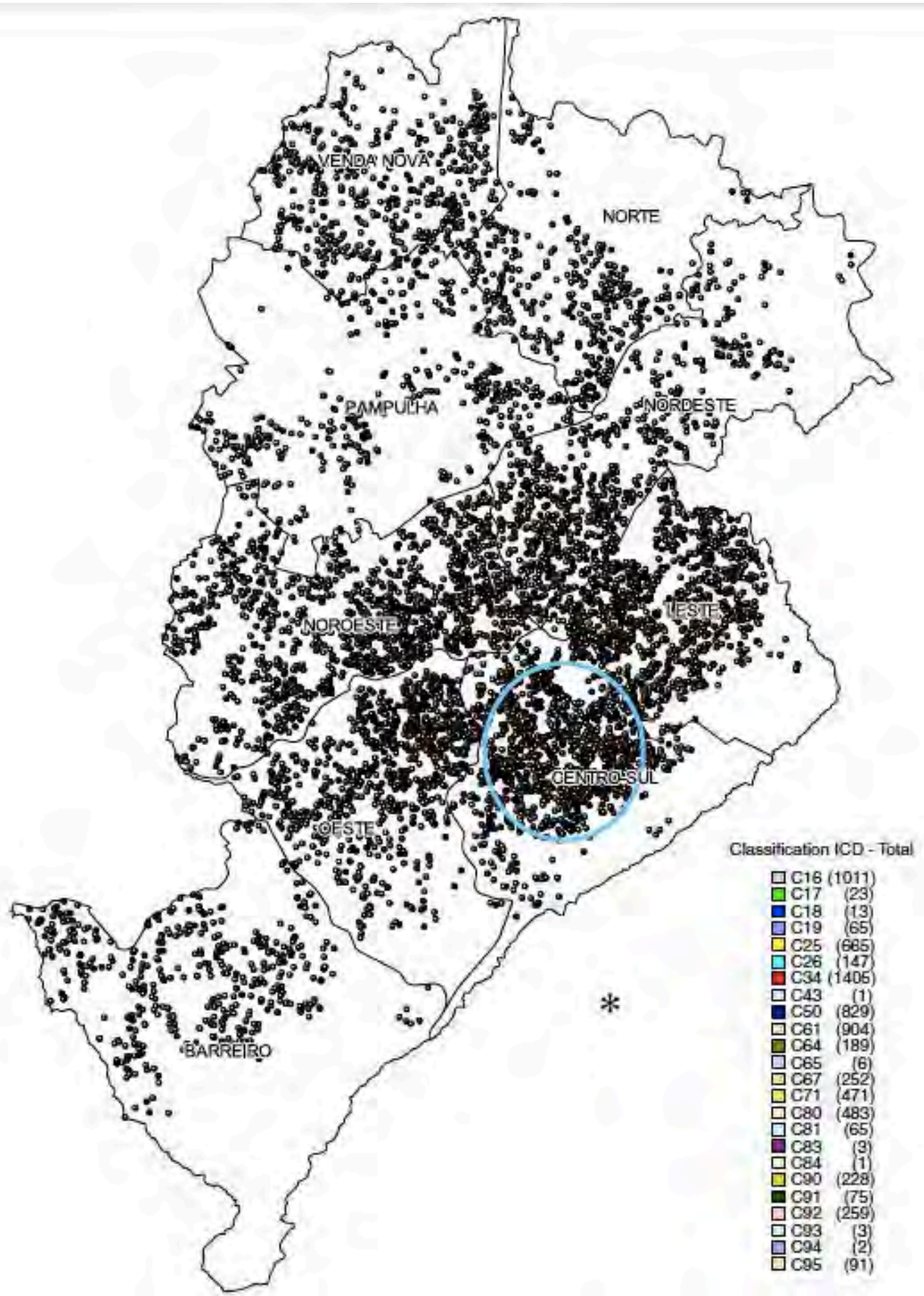

Fig. 7. Map of the total deaths by neoplasia in the Belo Horizonte municipality from 1996 to 2006, classified according to ICD. Total: 7191 deaths.

(C61), 12.57\%; and malignant neoplasm of breast (C50), 11.53\%. The largest absolute number of deaths was found in the Central-Southern region, followed by the Northwestern region. Also, the highest absolute numbers of lung cancer deaths (300 cases) and breast cancer deaths (210 cases) were found in Central-Southern SD (Table 2). The proportional mortality by gender can be seen in Figs. 13 and 14 .

\subsection{Estimates of the mortality rates by distance and time of exposure to BS}

The mortality rates were estimated by correcting the population mortality by 10,000 , according to the radius of distance from the BS within $1000 \mathrm{~m}$. In the region within $100 \mathrm{~m}$, the absolute number of deaths was 3569 (a percentage of $49.63 \%$ ), and the mortality rate was 43.42 persons per 10,000 inhabitants. Compared to with the total population mortality rate, the relative risk in this area was 1.35 . In the area up to $200 \mathrm{~m}$ there was a growth of 1408 deaths, a total of 4977 deaths, a mortality rate of 40.22 persons per 10,000 inhabitants and a relative risk of 1.25 (Table 5). In this way, the estimates of mortality by neoplasia were calculated inside radii up to $1000 \mathrm{~m}$ from the BSs. The relative risks presented a decreased dose-response gradient with residents' distance from the first licensed BSs.

Fig. 15 shows the mortality rate by neoplasia according to the distance from the BS in the Belo Horizonte municipality, during the studied period. The accumulated mortality rates by neoplasia, 


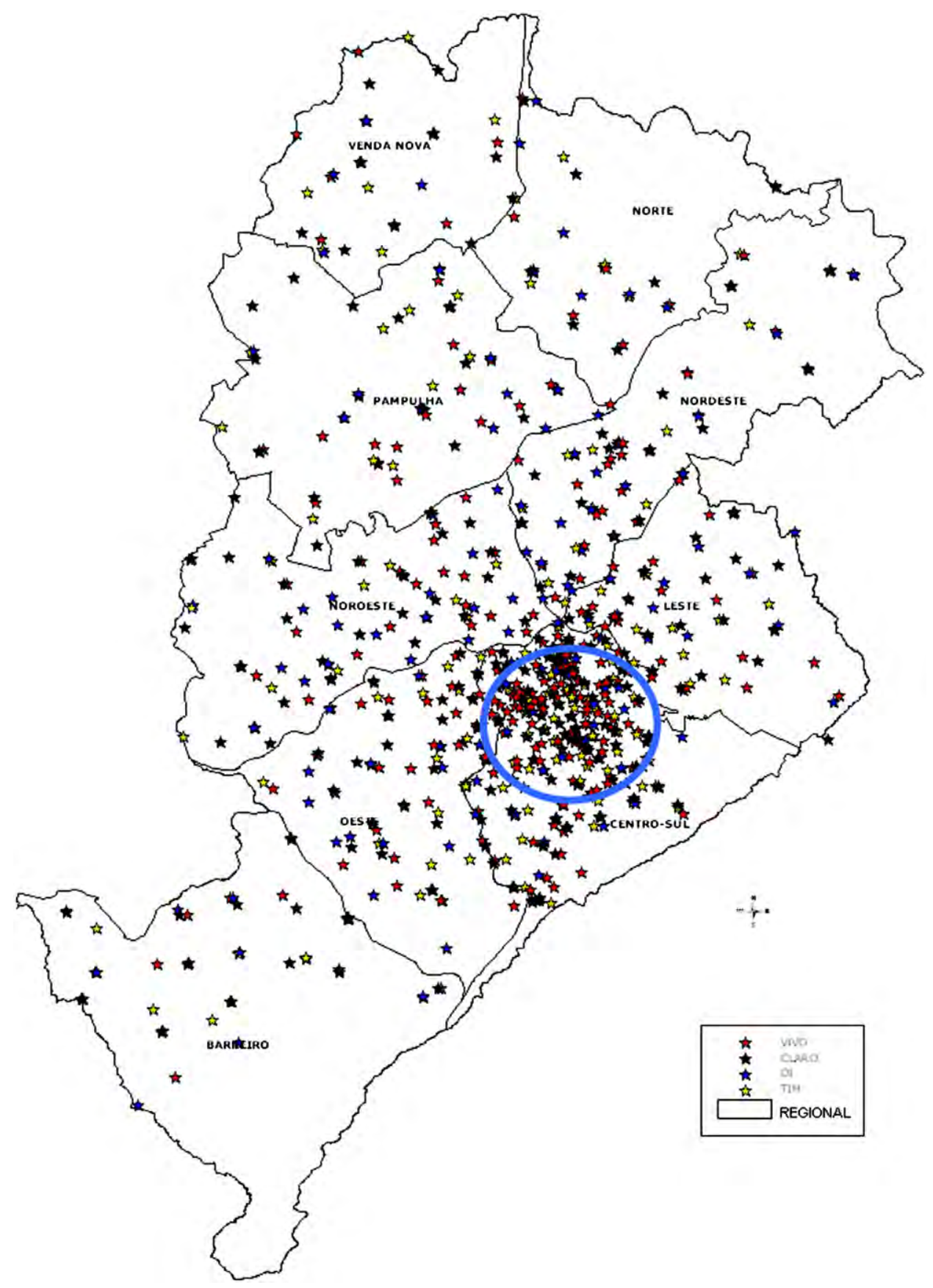

Fig. 8. Installed BSs in the Belo Horizonte municipality until 2006. Total amount $=856$.

determined by dividing the total number of deaths during the period $(\mathrm{n}=7191)$ by the total population living in the municipality $(2,238,332)$, showed that there was a risk of dying of 32.12 per 10,000 inhabitants, as seen in Fig. 15. In this study, this figure represents the null hypothesis, i.e., the total number of deaths occurring in the period divided by the population, independent of the proximity to the BSs. Fig. 16 shows the distribution of the number of deaths by neoplasia versus duration of exposure since the date of operation of the first antenna in each analyzed CT.

\subsection{Environmental monitoring of the electromagnetic field}

The EMF results provided essential information for the assessment of risks to the health of the exposed persons in the community. A total of
400 points were measured in the Central-Southern region in 2008, where a major concentration of cellular telephony antennas was found. The mean intensity of the measured electric field was $7.32 \mathrm{~V} / \mathrm{m}$, varying from 0.4 to $12.4 \mathrm{~V} / \mathrm{m}$. It was common to find a stronger electric field at locations above the ground. The BS frequency bands ranged from approximately $800 \mathrm{MHz}$ to $1800 \mathrm{MHz}$. In 2003, the power density varied from $0.898 \mu \mathrm{W} / \mathrm{cm}^{2}$ to $3.066 \mu \mathrm{W} / \mathrm{cm}^{2}$.

\section{Discussion}

Electric and EMFs interact with biological systems because they penetrate into organs and tissues, and the biological systems are ruled by delicate bioelectrochemical reactions that sustain the vital processes and receive the influence from those fields. As demonstrated in the literature 


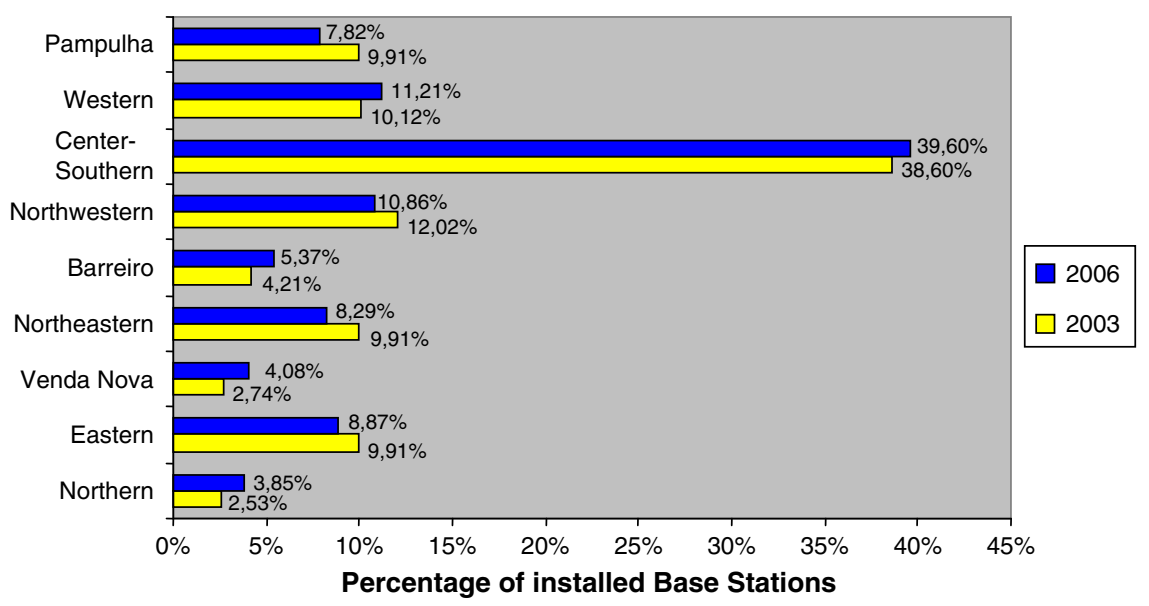

Fig. 9. BS percentage by Sanitary Districts in the Belo Horizonte municipality in 2003 and in 2006.

(Kundi and Hutter, 2009; Sage and Carpenter, 2009; Khurana, 2008; BIOINITIATIVE REPORT, 2007; Cherry, 2006; Cherry, 2007; Hardell and Sage, 2007), exposure to electromagnetic radiation of low intensities for long periods of time is a determinant for the aggravation and the emergence of diseases in humans. Studies point to observations of environmental carcinogens as an alert to the scientific community (Hardell et al., 2007). Bioeffects and adverse health effects occur at frequencies much lower than RF and extremely low frequencies (ELF), without any heating effect.

Khurana et al. (2010) identified by searching PubMed ten epidemiological studies that indicate the occurrence of neurobehavioral effects or cancer. In eight of those studies, the population lived within $500 \mathrm{~m}$ of a BS. However, all exposures were under the accepted international guidelines. Therefore, it is suggested that those guidelines may be inadequate in protecting the health of human populations. Additionally, more comprehensive epidemiological studies are necessary to evaluate long-term exposure to RF from mobile phones BSs to understand its health impact.

This research bases on the ecological study that uses geographical areas as units of pre-existing data to identify areas of risk. The data is already aggregated, and one does not know about the genetic characteristics, life habits, food choices and other factors of each individual. The ecological studies frequently begin the epidemiological process, and the discoveries are considered to be an alert.

In the Belo Horizonte municipality, the mortality rate was concentrated near the antennas and was not diffuse over the whole city. At a distance of up to $100 \mathrm{~m}$, the absolute number of deaths was $3569,49.63 \%$ of all deaths, the mortality rate was 43.42 persons per 10,000 and the relative risk was 1.35 . When one does not consider the distances from the BSs for all the entire population of the Belo Horizonte municipality $(2,238,332$ inhabitants), the mortality rate was 32.12 per 10,000 inhabitants, which is the null hypothesis.

In this research, we found a mortality rate for the residents living within $500 \mathrm{~m}$ of the transmitter antennas of a BS greater than 34.76 per 10,000 inhabitants. This rate decreased for residents living farther from the BS, as shown in Fig. 15.

We concluded that the relative risk of death by neoplasia, according to the distance from a BS in the Belo Horizonte municipality, from 1996 to 2006, was greater within a radius of up to $500 \mathrm{~m}$ from the BSs (Table 5). In the town of Netanya, Israel, in 2004, the authors also found an increase of 4.15 times in the cancer incidence of the residents of a zone up to $350 \mathrm{~m}$ from the BS, compared to those who lived outside that area (Wolf and Wolf, 2004). A retrospective study in Naila, Germany, showed that the risk of new cancer cases was three times greater among the patients who had lived at a distance less than $400 \mathrm{~m}$ from a cellular telephone transmitter antenna during the last ten years (1994 and 2004), compared to those who lived at greater distances (Eger et al., 2004).
In addition, only the deaths of those who were exposed since the first license date of the BS were included in the study, even though there were antennas that were installed in the register date (before the licensing date).

Also, we observed that the Central-Southern SD possessed the greatest antenna concentration in the city and the most electromagnetic contamination. This region contained $38.60 \%$ of the installed antennas in 2003 and 39.60\% in 2006. Again, through georeferencing, we observed a greater concentration of specific cases of death by neoplasia in the region. The accumulated incidence rate per 1000 residents was the largest in Central-Southern SD, reaching 5.83; this rate was the lowest (2.05) in Barreiro region.

In the Central-Southern SD, there are no factories; it is a strictly residential area, with some services and commerce. No power lines, highways, airports or railroads exist in the area. However, many private vehicles come and go in the region, and its inhabitants possess higher social status and affluence. It contains many wooded streets and gardens. The Central-Southern SD has other aggravating exposures, including noise, gases, fumes, aerodispersoids, and hydrocarbonates, each of which also damage human health. Despite the presence of diverse and aggressive potential agents that may have influenced the quality of life and the health of the dwellers living in the area, the mortality rates remained concentrated near the antennas, with a doseresponse gradient, and were not diffuse all over the city.

Age and sex did not appear to be a confounder in this study. In Belo Horizonte municipality, like all of Brazil, the population suffers from a demographic transition characterized by the aging of the population, and this is a possible confounder for all chronic degenerative diseases. Looking at the profile of the proportional mortality by age and gender throughout the 10 years studied, there is no specific trend for either men or women, and the highest percentage started at age 40 and increased to age 60. Irrespective of the year, the proportional mortality by gender and age remained stable during the period, suggesting there is no relevant change in the proportion of deaths by cancer when age is taken into consideration.

According to the ICNIRP guidelines, the human levels to the public at large (ICNIRP, 1998), for the frequency (f) band ranged from 400 to

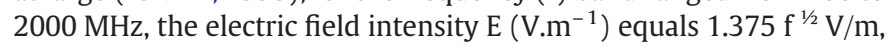
which equals $1.375 \sqrt{ } \mathrm{f} \mathrm{V} / \mathrm{m}$.

These values are according to the reference level patterns for the public at large when compared with the current Brazilian federal law which establishes the following limits: for a $900 \mathrm{MHz}$ field intensity an electric field of $41.25 \mathrm{~V} / \mathrm{m}$ and a power density of $451.34 \mu \mathrm{W} / \mathrm{cm}^{2}$, for a $1800 \mathrm{MHz}$ field intensity an electric field of $58.33 \mathrm{~V} / \mathrm{m}$ and a power density of $902.49 \mu \mathrm{W} / \mathrm{cm}^{2}$. These human exposure limits are exclusively based on thermal effects. 


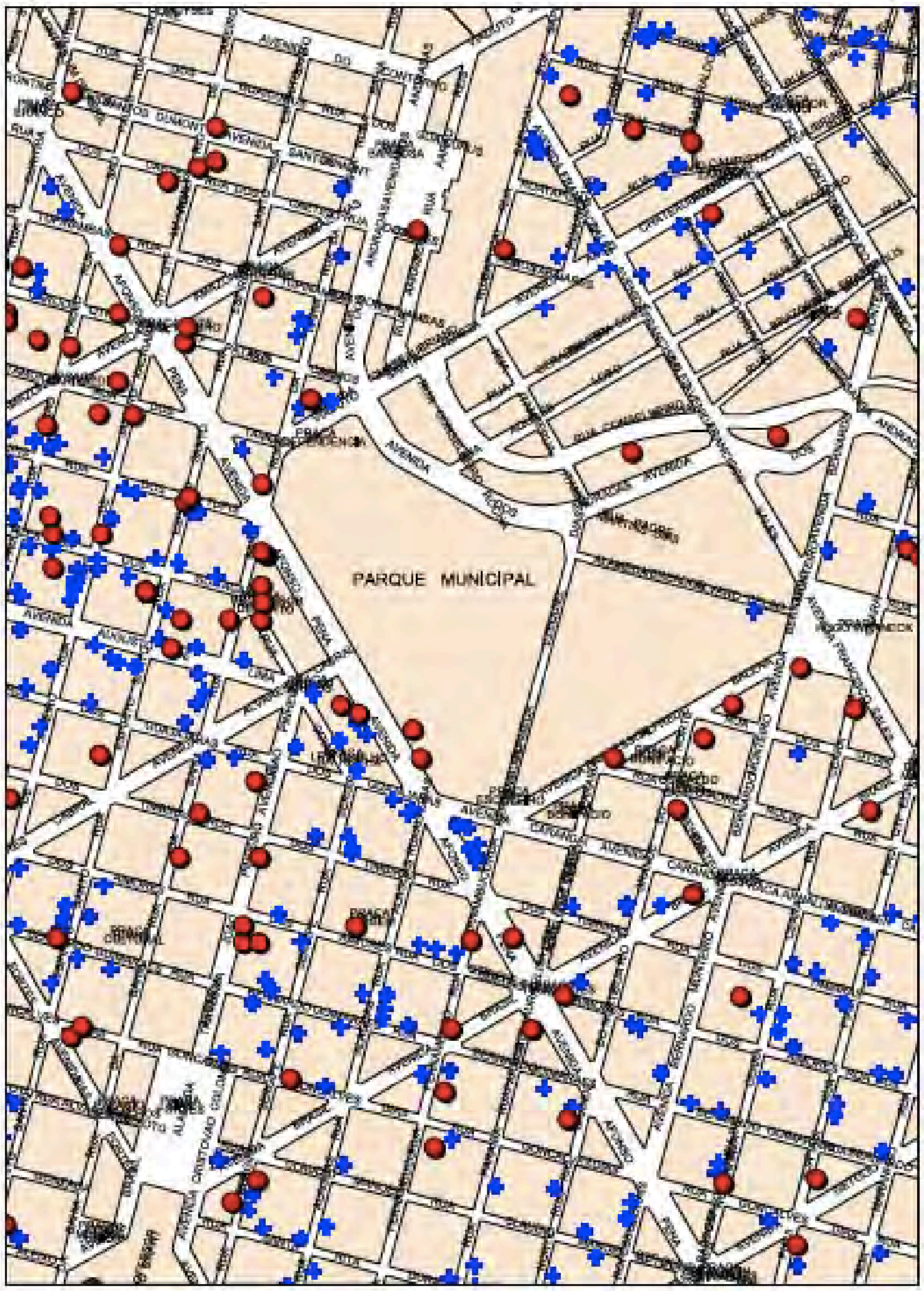




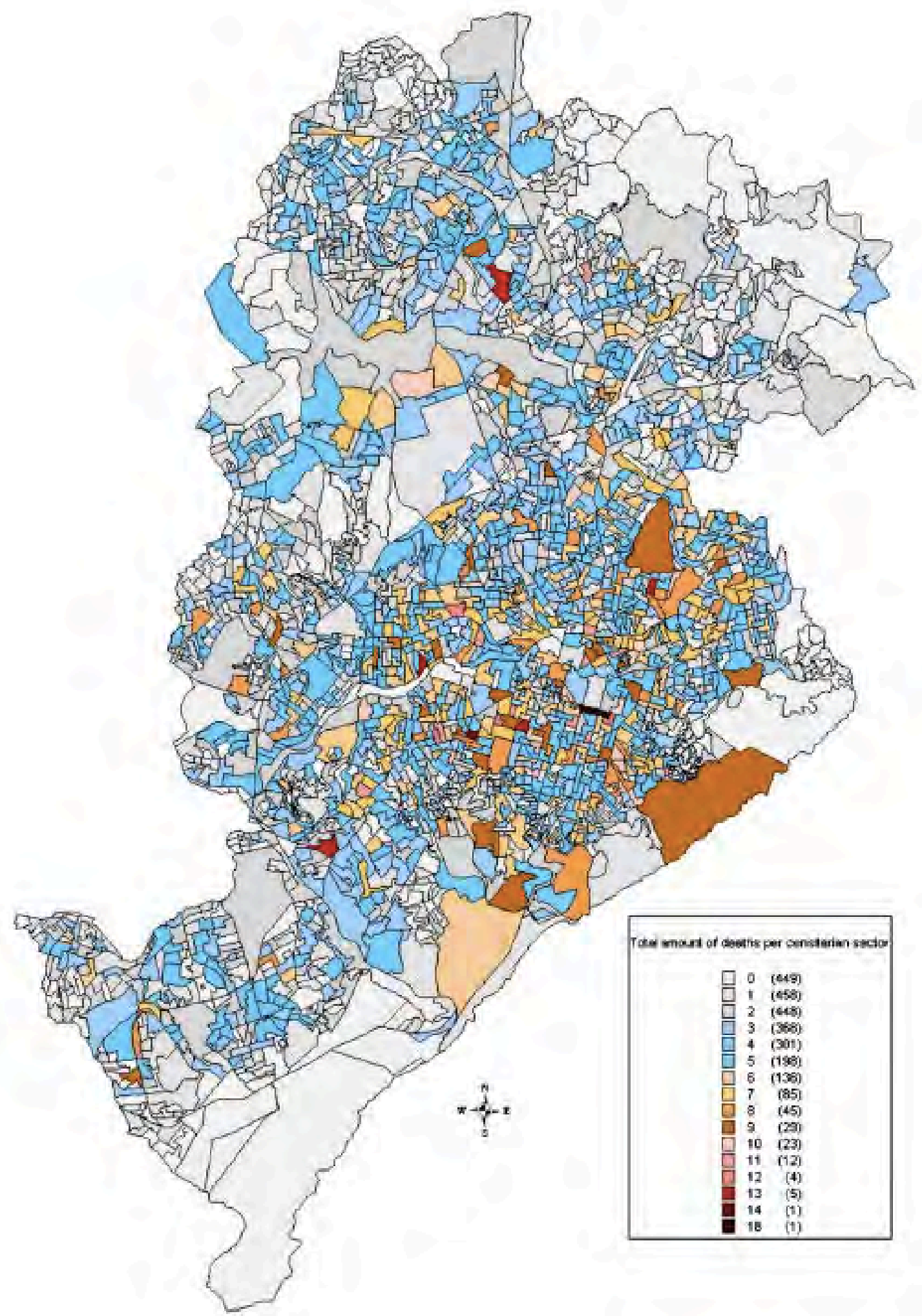

Fig. 11. Map of 7191 cancer deaths geocoded by CT.

In 2003, the largest electric field found during environmental monitoring of the BSs was $3.4 \mathrm{~V} / \mathrm{m}$ and the greatest power density was $3.06 \mu \mathrm{W} / \mathrm{cm}^{2}$. In 2008 , the largest electric field found during environmental monitoring of the BSs was $12.4 \mathrm{~V} / \mathrm{m}$, and the greatest power density was $40.78 \mu \mathrm{W} / \mathrm{cm}^{2}$ near the cellular antennas in the 890 to $1800 \mathrm{MHz}$ frequency band. These values were much larger than those reported in the Netanya study (approximately $0.53 \mu \mathrm{W} / \mathrm{cm}^{2}$ ). The smallest values found in the measurements were a field intensity of $0.4 \mathrm{~V} / \mathrm{m}$ and a power density of $0.04 \mu \mathrm{W} / \mathrm{cm}^{2}$. 


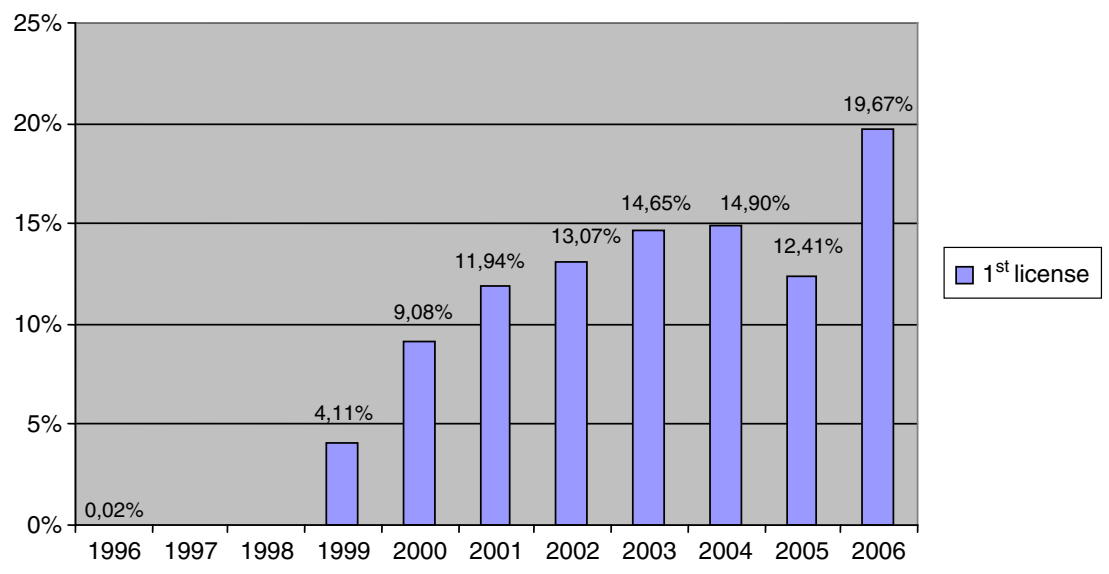

Fig. 12. Percentage of neoplasia deaths per year in the Belo Horizonte municipality, from 1996 to 2006, using the first license date.

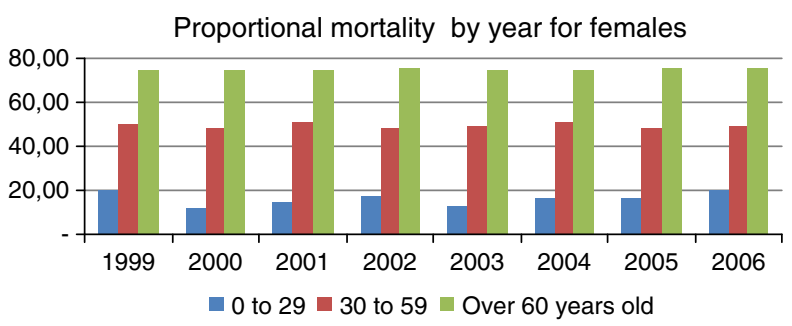

Fig. 13. Proportional mortality by year for females.

The major advantage of this ecological study is that it is the first epidemiological approach to determine the existence of a possible association between a determined exposure and a health outcome using the group characteristics.

The principal limitations of the present study concern the study design and the use of secondary data. By design, the group results could not be extrapolated to each person in the population. Although the data were well standardized and collected from official personnel in the City Health Department, they are subject to misclassification due to lack of information and errors in the entering of data and diagnosis. Finally, neither the life habits nor the genetic factors of the residents could be taken into account.

Despite these limitations, the present study has brought important contributions to the issue, the most important of which is the existence of a cluster of deaths by neoplasia associated with BS clusters. Although the direction of this relationship could not be specified, this work has demonstrated the existence of such clusters. Until more extensive studies are conducted, we urge the adoption of the Precautionary Principle and a revision of national policies toward stronger restrictions of the human limits associated with this

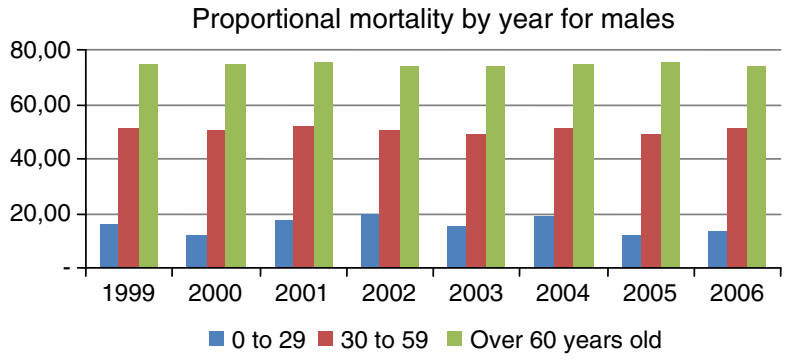

Fig. 14. Proportional mortality by year for males. technology. The adoption of EMF and radiation levels similar to the more restrictive exposure limits of many other countries and towns would be one important public health provision. On this matter, we refer to the Porto Alegre Resolution.

The Precautionary Principle states that when there are signs of possible adverse effects to health or to the environment, although uncertain, the risks of inaction can be greater than the risks of acting, especially in relation to the control of human exposures to nonionizing radiation. The Precautionary Principle reverses the burden of proof from those who suspect a risk on those who take the actions and affirm that only when new scientific discoveries will be recognized as the unique criterion to establish or to change guidelines. The principle asserts that precaution be maintained until new proven researches be done.

From May 18th to 19th, 2009. in Porto Alegre City, Rio Grande do Sul State, Brazil, occurred The International NIR (Non-Ionizing Radiation) and Health Workshop ("Seminário Internacional sobre RNI, a Saúde e o Ambiente"), sponsored by the Federal University of Rio Grande do Sul. The purpose of the workshop was to present lectures as a basis to initiate discussions among Brazilian and foreign scientists and public health authorities on the potential biological and health consequences and the setting of exposure limits of nonionizing electromagnetic fields/radiation (NIR).

The workshop also was under the sponsorship of the Brazilian Ministry of Health, as well as some other governmental and non-

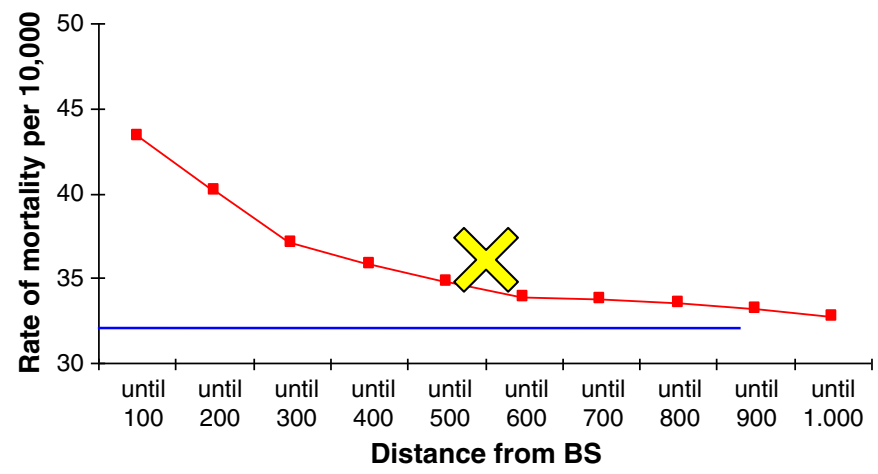

_ Rate of mortality by neoplasia, according to the distance from BS

Null hypothesis

Fig. 15. Rate of mortality by neoplasia, according to the distance from the BS in Belo Horizonte municipality, from 1996 to 2006, and the null hypothesis. 


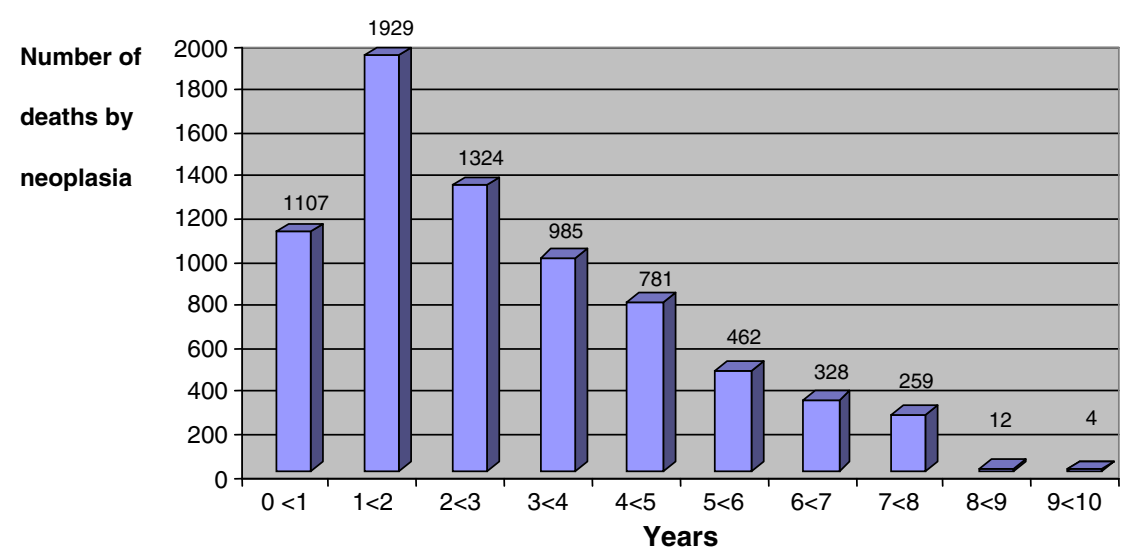

Fig. 16. Distribution of the number of deaths by neoplasia versus duration of exposure since the date that the first antenna in each analyzed CT came into operation.

governmental organizations. International researchers from several countries delivered talks on selected subjects.

Researchers, public health authorities, as well as authorities from the legislative, executive and judiciary governmental bodies from Brazil and other South American countries were also present.

\section{Site: www.ufrgs.br/ppgee/rni.htm}

After the event, the Porto Alegre Resolution was approved by the scientists from many countries and participants who have understood that the health protection, the well-being and the environment require the immediate adoption of the Precautionary Principle and some precautionary practices. pdf

Site: http://www.icems.eu/docs/resolutions/Porto_Alegre_Resolution.

\section{Conclusion}

This research showed the existence of a spatial correlation between cases of death by neoplasia and the locations of the BSs, in the Belo Horizonte municipality from 1996 to 2006.

The mortality rates and the relative risk were higher for the residents inside a radius of $500 \mathrm{~m}$ from the BS, compared to the average mortality rate of the entire city, and a decreased doseresponse gradient was observed for residents who lived farther away from the BS. The major antenna concentration was located in the Central-Southern SD of the city, which also had the largest accumulated incidence (5.83/1000 inhabitants).

The measured values of the EMF, determined in 2008 and 2003, were substantially below the values allowed by the Brazilian federal law nr. 11934, May 5, 2009. Nevertheless, the values encountered in this study surpassed the limits of human exposure adopted by many other countries and cities in the world, including Italy $\left(10 \mu \mathrm{W} / \mathrm{cm}^{2}\right)$; China $\left(6.6 \mu \mathrm{W} / \mathrm{cm}^{2}\right)$; Switzerland $\left(4.2 \mu \mathrm{W} / \mathrm{cm}^{2}\right)$; Paris, France $(1 \mu \mathrm{W} /$ $\left.\mathrm{cm}^{2}\right)$; Salzburg, Austria $\left(0.1 \mu \mathrm{W} / \mathrm{cm}^{2}\right)$; and Porto Alegre, Brazil $\left(4.2 \mu \mathrm{W} / \mathrm{cm}^{2}\right)$.

New epidemiological studies must explore this issue with more timely and appropriate methodology to provide evidence that may confirm the relationship between risk and hazard at an individual level. Meanwhile, we strongly suggest the adoption of the Precautionary Principle until the limits of human exposure, as established in Brazilian Federal Law, can be re-evaluated.

Supplementary materials related to this article can be found online at doi:10.1016/j.scitotenv.2011.05.051.

\section{Acknowledgements}

We would like to thank Márcia Salvador Géo, Medical Doctor; Helvécio Miranda Magalhães Júnior, Medical Doctor; Luciano Assírio Bossi, Telecommunications Engineer; Graziella Lage Oliveira, Psychologist; Lívia Daniella Pereira Dode, Production Engineer; and Aline Dayrrel Ferreira Sales, Epidemiologist for their kind and ever-present support.

\section{References}

Alanko T, Hietanen M, von Nadelstadh P. Occupational exposure to RF fields from base station antennas on rooftops. Annals of telecommunications. From the issue entitled "Health protection and RF exposure assessment: engineering aspects, 63. ; 2008 p. 125-32.. Numbers 1-2, DOI: 01007/s12243-007-0001-6.

ANATEL. [online] Available from: <www.anatel.gov.br> 21st April, 2011.

ANATEL - "Agência Nacional de Telecomunicação": "Telecommunications Nationa Agency. Resolução no. 303 de 2 de julho de 2002 - Aprova o Regulamento sobre Exposição a Campos Elétricos, Magnéticos e Eletromagnéticos na Faixa de Radiofreqüências entre $9 \mathrm{kHz}$ e $300 \mathrm{GHz}$. (Resolution nº. 303, July 2nd, 2002 - Approves the Regulation on Exposure to Electric, Magnetic and Electromagnetic Fields in the Radiofrequencies Band from $9 \mathrm{kHz}$ to $300 \mathrm{GHz}$.); 2000a. [online]. Available from: $<$ www.anatel.gov.br>.

ANATEL - "Agência Nacional de Telecomunicações": 'Telecommunications National Agency'.. Anexo à Resolução no. 303 de 2 de julho de 2002 - Regulamento sobre Limitação da Exposição a Campos Elétricos, Magnéticos e Eletromagnéticos na Faixa de Radiofreqüências entre $9 \mathrm{kHz}$ e $300 \mathrm{GHz}$. (Annex to Resolution nº. 303, July 2nd 2002 - Regulation on Exposure to Electric, Magnetic and Electromagnetic Fields in the Radiofrequencies Band from $9 \mathrm{kHz}$ to $300 \mathrm{GHz}$.); 2000b. [online]. Available from: www.anatel.gov.br.

Beall C, Delzell E, Cole P, Brill I. Brain tumors among electronics industry workers. Epidemiology 1996;7:125-30.

Beniashvili D, Avinoach I, Baazov D, Zusman I. Household electromagnetic fields and breast cancer in elderly women. May-Jun;In Vivo 2005;19(3):563-6. 2005. [online] Available from: <http://www.ncbi.nlm.nih.gov/pubmed/15875777>. May 2nd, 2008

BIOINITIATIVE REPORT: A rationale for a biologically-based public exposure standard for electromagnetic fields (ELF and RF). [online]. 2007. Available from: <http:// www.bioinitiative.org $>$, in 2010.

BRAZIL. Ministry of Health. [online]. Available from www.saude.gov.br. 2011.

Cherry N. Scientific evidence of the risk of adverse health effects from chronic exposure to low-level electromagnetic radiation - EMRAA, Electromagnetic Radiation Alliance of Australia, E-mail: emraa@ssec.org.au, Sept. 1999.

Cherry N. Health effects associated with mobile base stations in communities: the need for health studies. New Zealand: Lincoln University - Environmental Management and Design Division, 8 June 2000; 2007.. [online]. Available on Dec. 2006. Sep.

Dode, Adilza Condessa. Poluição ambiental e exposição humana a campos eletromagnéticos: estudo de casos no município de Belo Horizonte com ênfase nas estações radiobase de telefonia celular. (Environmental pollution and human exposure to electromagnetic fields: a case study in Belo Horizonte municipality emphasizing mobile phone base stations). Dissertação: Mestrado em Saneamento, Meio Ambiente e Recursos Hídricos - Escola de Engenharia, Universidade Federal de Minas Gerais, Belo Horizonte. (Thesis: Master Degree in Sanitation, Environment and Hydric Resources - Engineering School, Federal University of Minas Gerais, Belo Horizonte City, Brazil). p175. 2003.

Eger H, Jahn M. Specific health symptoms and cell phone radiation in Selbitz (Bavaria, Germany) - evidence of a dose-response relationship. Umwelt-Medizin-Gesellschaft 2010;23:2. 
Eger $\mathrm{H}$, Hagen $\mathrm{Ku}$, Lucas B, Vogel P, Voit $\mathrm{H}$. Einfluss der räumlichen Nähe von Mobilfunksendeanlagen auf die Krebsinzidenz. Umwelt-Medizin-Gesellschaft 2004; $17: 4$.

Feychting M, Forssen U, Floderus B. Occupational and residential magnetic field exposure and leukemia and central nervous system tumors. Epidemiology 1997;8: 384-9.

Gadzicka E, Bortkiewics A, Zmyslony M, Szymczak W, Szyjkowska A. Assessment of subjective complaints reported by people living near mobile phone base stations [Abstract]. Biuletyn PTZE Warszawa 2006;14:23-6.

GORDIS L. Epidemiologia. Translation from English: 'Epidemiology'. 2. ed. Rio de Janeiro: Revinter; 2004.. 302p.

Guenel P, Nicolau J, Imbernon E, Chevalier A, Goldberg M. Exposure to 50-Hz electricfield and incidence of leukemia, brain tumors and other cancers among French electric utility workers. Am J Epidemiol 1996;144:1107-21.

Hallberg JO. Malignant melanoma of the skin - not a sunshine story! Med Sci Monit Jul 2004;10(7):CR336-40. (Electronic publication ahead of print, 2004 Jun 29).

Hardell L, Sage C. Biological effects from electromagnetic field exposure and public exposure standards; 2007. doi:10.1016/j.biopha.2007.12.004.. [online]. Available from: $<$ www.sciencedirect.com $>$. Dec.

Hardell L, Carlberg M, Ohlson C-G, Westberg H, Eriksson M, Hansson Mildt K. Use of cellular and cordless telephones and risk of testicular cancer. Int J Androl 2007;30: $115-22$.

IBGE - Instituto Brasileiro de Geografia e Estatística ('Brazilian Institute of Geography and Statistics'). Censo Demográfico (Demographic Census) 2000.[online]. Available from: <www.ibge.gov.br/censo>. Apr. 2008.

IBGE - Instituto Brasileiro de Geografia e Estatística ('Brazilian Institute of Geography and Statistics'). Censo Demográfico (Demographic Census) 2010. [online]. Available from: <www.ibge.gov.br/censo>. May 2011.

ICNIRP - International Commission on Non-Ionizing Radiation Protection. Guidelines for limiting exposure to time varying electric, magnetic and electromagnetic fields (up to $300 \mathrm{GHz}$ ). Health Phys 1998;74:494-522. April 1998.

IEEE - Institute of Electrical Electronics Engineers Inc. IEEE - IEEE recommended practice for the measurement of potentially hazardous electromagnetic fields - RF and microwave. IEEE - C95.3-1991(Revision of ANSI C95.3-1973 and ANSI C 95.5-1981), New York, USA; 1992.

IEEE - Institute of Electrical Electronics Engineers Inc. IEEE standard for safety levels with respect to human exposure to radio frequency electromagnetic fields, $3 \mathrm{kHz}$ to 300 GHz. IEEE - C95.1. 1999 Edition (Incorporating IEEE Std C95.1-1991 and IEEE Std C95.1a-1998), New York, USA; 1999.

Johansson O. Electrohypersensitivity: state-of-the-art of a functional impairment. Electromagn Biol Med 2006;25:245-58.

KATHEREIN MOBILCOM BRASIL LTDA. HUEMER E., LENSIG Kl-. Guia prático de antenas ('Practical guide of antennas'). Dinâmica Gráfica e Editora Ltda. 2로로ão. São Paulo. 52p. 1999.
Khurana VG. Mobile phones and brain tumours - (c); 2008.. G. Khurana - All Rights Reserved. [online]. Available from: <www.brain-surgery.us>. Apr. 2008.

Khurana VG, Hardell L, Everaert J, Bortkiewicz A, Carlberg M, Ahonen M. Epidemiological evidence for a health risk from mobile phone base stations. Int J Occup Environ Health 2010;16. no. 3, Jul/Sep.

Kundi M, Hutter HP. Mobile phone base stations - Effects on wellbeing and health. Pathophysiology (2009) (PATPHY-597). doi10.1016/j.pathophys.2009.01.008. Elsevier Ireland Ltd. 13 pp. Accepted 30 January 2009.

Lai H. Biological effects of radiofrequency radiation from wireless transmission towers; a presentation at the "Cell Tower Forum: State of the Science/State of the Law" sponsored by the Berkeshire-Lichtfield Environmental Council on December 2, 2000, in Lakeville, CT, USA. [online]. Available from: <http://www.indymedia.ie/ attachments/jul2007/henrylai_bioeffectsfromtowers1.pdf >. Apr. 2011.Apr. 2008.

Mack W, Preston-Martin S, Peters JM. Astrocytoma risk related to job exposure to electric and magnetic fields. Bioelectromagnetics 1991;12. 57e66.

NATIONAL COUNCIL ON RADIATION PROTECTION AND MEASUREMENTS NCRP-. Report n.. 119 - A practical guide to the determination of human exposure to radiofrequency fields. Maryland, USA: Bethesda; 1993.. ISBN 0-929600-35-5.

Navarro EA, Segura J, Portolés M, Gómez-Perretta C. The microwave syndrome: a preliminary study in Spain. Electromagn Biol Med 2003;Vol. 22(N. ㅇ 283):161-9. USA.

Sage C, Carpenter DO. Public health implications of wireless technologies. . (PATPHY-603). Pathophysiology 2009. doi:10.1016/j.pathophys.2009.01.011. Elsevier Ireland Ltd. 14 pp. Accepted 30 January 2009

Santini R, Santini P, Danze JM, Le Ruz P, Seigne M. Enquête sur la santé de riverains de stations relais de téléphonie mobile: I/Incidences de la distance et du sexe. Pathol. Biol. (Paris) 2002;50:369-73.

Santini R, Santini P, Danze JM, Le Ruz P, Seigne M. Enquête sur la santé de riverains de stations relais de téléphonie mobile: II/Incidences de l'âge des sujets, de la durée de leur exposition et de leur position par rapport aux antennes et autres sources électromagnétiques. Pathol.Biol. (Paris) 2003;51:412-5.

Schoemaker MJ, Swerdlow AJ, Ahlbom A, et al. Mobile phone use and risk of acoustic neuroma: results of the interphone case-control study in five North European countries. Br J Cancer 2005;93:842-8.

Stang A. Federal Ministry for Education and Research of Germany. The possible role of radiofrequency radiation in the development of uveal melanoma. Epidemiology 2001; vol. 12(n. ${ }^{\circ}$ 1):7-12.

UN - Population Crisis Committee of the United Nations. 2007.

UNDP - United Nations Development Programme. In Amaral E., Thesis of Postgraduate degree in management and assessment of social projects in urban areas, Sociology and Anthropology Department, Human Sciences and Philosophy, Federal University of Minas Gerais - UFMG. 2008.

Wakeford R. The cancer epidemiology of radiation. Oncogene 2004;23. 6404e28.

Wolf R, Wolf D. Increased incidence of cancer near a cell-phone transmitter station. Int J Cancer Prevention April 2004;1(2). 